\title{
Carbon prices and CCS investment: comparative study between the European Union and China
}

\author{
Marie Renner ${ }^{1}$
}

As policy makers assess strategies to reduce greenhouse gas emissions (GHG), they need to know the available technical options and the conditions under which these options become economically attractive. Carbon Capture and Storage (CCS) techniques are widely considered as a key option for climate change mitigation. But integrating CCS techniques in a commercial scale power plant adds significant costs to the capital expenditure at the start of the project and to the operating expenditure throughout its lifetime. Its additional costs can be offset by a sufficient $\mathrm{CO} 2$ price but most markets have failed to put a high enough price on CO2 emissions: currently, the weak Emission Unit Allowances price threatens CCS demonstration and deployment in the European Union (EU). A different dynamic is rising in China: a carbon regulation seems to appear and CCS techniques seem to encounter a rising interest as suggest their inclusion in the 12th Five-Year Plan and the rising number of CCS projects identifies/planned. However, there are very few in-depth techno-economic studies on CCS costs. This study investigates two related questions: how much is the extra-cost of a CCS plant in the EU in comparison with China? And then, what is the $\mathrm{CO} 2$ price beyond which CCS power plants become more profitable/economically attractive than classic power plants, in the EU and in China? To answer these questions, I first review, analyze and compare public studies on CCS techniques in order to draw an objective techno-economic panorama in the EU and China. Then, I develop a net present value (NPV) model for coal and gas plants, with and without CCS, in order to assess the $\mathrm{CO} 2$ price beyond which CCS plants become the most profitable power plant type. This $\mathrm{CO} 2$ value is called $\mathrm{CO} 2$ switching price. I also run some sensitivity analyses to assess the impact of different parameter variations on this $\mathrm{CO} 2$ switching price. I show that CCS power plants become the most profitable baseload power plant type with a $\mathrm{CO} 2$ price higher than $70 € / \mathrm{t}$ in the EU against $30 € / \mathrm{t}$ in China, without transport and storage costs. When the $\mathrm{CO} 2$ price is high enough, CCS gas plants are the most profitable power plant type in the EU whereas these are CCS coal plants in China. Through this study, I advise investors on the optimal power plant type choice depending on the $\mathrm{CO} 2$ market price, and suggest an optimal timing for CCS investment in the EU and China.

1. University Paris Ouest Nanterre La Défense and Climate Economics Chair marie.renner@chaireeconomieduclimat.org

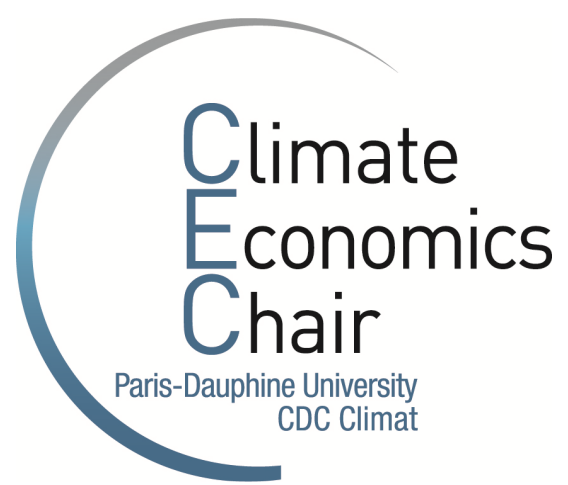





\begin{abstract}
As policy makers assess strategies to reduce greenhouse gas emissions (GHG), they need to know the available technical options and the conditions under which these options become economically attractive. Carbon Capture and Storage (CCS) techniques are widely considered as a key option for climate change mitigation. But integrating CCS techniques in a commercial scale power plant adds significant costs to the capital expenditure at the start of the project and to the operating expenditure throughout its lifetime. Its additional costs can be offset by a sufficient $\mathrm{CO}_{2}$ price but most markets have failed to put a high enough price on $\mathrm{CO}_{2}$ emissions: currently, the weak Emission Unit Allowances price threatens CCS demonstration and deployment in the European Union (EU). A different dynamic is rising in China: a carbon regulation is setting up and CCS techniques seem to encounter a rising interest as suggest their inclusion in the $12^{\text {th }}$ Five-Year Plan and the rising number of CCS projects identifies/planned. However, there are very few in-depth techno-economic studies on CCS costs. This study investigates two related questions: how much is the extra-cost of a CCS plant in the EU in comparison with China? And then, what is the $\mathrm{CO}_{2}$ price beyond which CCS power plants become more profitable/economically attractive than classic power plants, in the EU and in China? To answer these questions, I first review, analyze and compare public studies on CCS techniques in order to draw an objective techno-economic panorama in the EU and China. Then, I develop a net present value (NPV) model for coal and gas plants, with and without CCS, in order to assess the $\mathrm{CO}_{2}$ price beyond which CCS plants become the most profitable power plant type. This $\mathrm{CO}_{2}$ value is called $\mathrm{CO}_{2}$ switching price. I also run some sensitivity analyses to assess the impact of different parameter variations on this $\mathrm{CO}_{2}$ switching price. I show that CCS power plants become the most profitable baseload power plant type with a $\mathrm{CO}_{2}$ price higher than $115 € / t$ in the $\mathrm{EU}$ (offshore transport and storage costs) against $33 € / \mathrm{t}$ (onshore transport and storage costs) or $47 € / t$ (offshore transport and storage costs) in China. When the $\mathrm{CO}_{2}$ price is high enough, CCS gas plants are the most profitable power plant type in the EU whereas these are CCS coal plants in China. Through this study, I advise investors on the optimal power plant type choice depending on the $\mathrm{CO}_{2}$ market price, and suggest an optimal timing for CCS investment in the EU and China.
\end{abstract}

\title{
Introduction
}

To reduce anthropogenic greenhouse gas (GHG) emissions responsible for climate change and limit long-term global temperature increase to $2^{\circ} \mathrm{C}$ (COP 15), the four main technical options to be combined are: (1) a massive development of clean energies (renewable and nuclear), (2) the reduction of fossil fuel consumption by switching to lower-carbon alternatives (E.g.: coal to gas), (3) efficiency of energy demand and of technologies used to convert fossil fuels into energy, particularly in power generation and (4) carbon capture and storage techniques (CCS) (BERNSTEIN L. et al., 2006). CCS is a suite of techniques designed to capture the $\mathrm{CO}_{2}$ contained in industrial flue gases from large point sources (fossil fuel plants, blast furnaces, cement manufacturing...) before it is emitted to the atmosphere, to transport it (E.g. pipelines) and then to inject it into a suitable storage facility (E.g. depleted oil and gas fields and deep saline aquifers).

International organizations like the European Commission (Roadmap 2050, 2011), the IPCC (2005, 2007), the IEA $(2010,2012,2013)^{1}$, the ZEP $(2011)^{2} \ldots$ present CCS as the only current mitigation

${ }^{1}$ International Energy Agency. 
technology that would allow industrial sectors (such as iron and steel, cement and fossil fueled power plant) to meet deep emission reduction targets. Thus, energy scenarios with ambitious climatic goals use CCS techniques. In its ${ }^{3}$ analysis (IEA, 2013), the IEA develops a 2DS scenario in which CCS technologies play an important part in the energy system that allows to meet the $2^{\circ} \mathrm{C}$ goal: CCS could account for up to $20 \%$ of the total emission reductions globally through 2050 . About half of the total volume of the captured carbon comes from the industry and the other half from the power sector.

CCS techniques applied to the power sector offer a significant potential to reduce GHG emissions: in 2009 , power generation contributed to $40 \%$ of total $\mathrm{CO}_{2}$ atmospheric emissions (IEA, 2012a). Around two thirds of the world's electricity was generated from fossil fuels, with $40 \%$ from coal, $21 \%$ from natural gas and 5\% from oil, and the use of coal and gas to generate electricity is still rising (IEA, 2012a). Therefore this paper focuses on the power sector.

Abandoning CCS as a mitigation option would increase the investment requested in the power sector by $40 \%$, which means an extra cost of USD 2 trillion over 40 years (BEST D. et al., 2012). Even if CCS techniques remain capital intensive and costly, they can be "competitive on a levelised cost of electricity (LCOE) basis with solar, wind (...)" (IEA, 2012c). Indeed, one might tend to focus on the high extra-costs of CCS power plants without replacing them in the merit order of low carbon energies. Moreover, CCS power plants present a significant advantage upon renewable energies: the electricity can be supplied on demand and do not suffer intermittency.

Therefore, while their energy demand is still growing and their energy mix fossil fuel dependent, the European Union and China consider CCS as an important technology to reduce $\mathrm{CO}_{2}$ emissions from power plants (GRIMSTON et al., 2001).

In the late 2000s, the EU viewed CCS techniques as able to play a critical role in meeting its climate targets, well known as the "20-20-20" in the climate and energy package framework (2009) ${ }^{4}$. Thus the EU has committed to support CCS, from a financial and regulatory point of view. Following the European Council's decision (2007) to support up to 12 large-scale demonstration projects by 2015, the Commission took several regulatory measures. Among them, the CCS Directive that was adopted to provide a legal and common framework for $\mathrm{CO}_{2}$ capture, transport and storage, with a transposition deadline set at June 2011. $\mathrm{CO}_{2}$ transport pipelines were included in the Europe's Energy Infrastructure Priorities (EIP) (2010) and in the Regulation on "Guidelines for Trans-European Energy Infrastructure" (2013). To establish a demonstration support framework, CCS has become an integral part of the EU R\&D program, in the frame of the European Industrial Initiative (EII) on CCS that is part of the Strategic Energy Technology (SET) Plan. Two funding instruments have also been created: the European Energy Program for Recovery (EEPR) ${ }^{5}$ and the $\mathrm{NER}^{6} 300$; in 2008, the EU agreed to set aside 300 million Emission Unit Allowances (EUA) from the NER under the European Union-Emission Trading System (EU-ETS) Directive. This financing instrument is dedicated to subsidy installations of innovative renewable energy technology and CCS. However, the current weak EUA price slows down CCS demonstration and deployment ${ }^{7}$. The

\footnotetext{
${ }^{2}$ Zero Emission Platform. Founded in 2005, the European Technology Platform for Zero Emission Fossil Fuel Power Plants is a coalition of stakeholders united in their support for CCS as a key technology for combating climate change. ZEP serves as advisor to the European Commission on the research, demonstration and deployment of CCS. 300 experts from 19 countries and around 40 companies and organizations contribute to ZEP's activities.

${ }^{3}$ Energy Technology Perspectives.

${ }^{4}$ A $20 \%$ reduction in GHG emissions from 1990 levels, raising the share of EU energy consumption produced from renewable resources to $20 \%$, a $20 \%$ improvement in the EU's energy efficiency.

${ }^{5}$ http://www.developpement-durable.gouv.fr/IMG/pdf/26-_captage_et_le_stockage_du_CO2.pdf

${ }^{6}$ New Entrance Reserve (NER).

${ }^{7}$ No CCS projects were selected in the first call for proposals of NER300; one project has been submitted in the second call, for which Awards are envisaged by mid-2014.
} 
lack of large scale pilots threatens CCS deployment in Europe. As a result, as other countries like China currently invest in CCS, the European Union could lose its leadership ${ }^{8}$ in the CCS field.

If a CCS cooling has been observed in the EU over the past few months, CCS seems to have received a fresh boost in China. Indeed, China has recently shown the willingness to reduce its GHG emissions with the goal to reduce its carbon intensity by $40 \%$ to $45 \%$ from 2005 levels by 2020 (WU N. et al., 2013). But coal share in the Chinese power mix was $78 \%$ in 2010 and will remain dominant in 2020 with 60\% (IEA, 2012a). Thus, CCS has a high potential market in China. The inclusion of CCS in China's $12^{\text {th }}$ Five-Year Plan reflects a strong commitment in CCS development and deployment. China has now 11 Large Scale Integrated Projects (LSIPs) planning ( 9 in the evaluate stage, 2 in the identify stage) compared to five in 2010, ranking second to the United States (19) in terms of the LSPI numbers (GCCSI, 2013). However, note that American LSPIs are in more advanced stages (7 evaluate, 8 define, 4 execute, 2 operate). Moreover, Chinese investment and Operation and Maintenance (O\&M) costs are lower than in OECD countries. So CCS plants could be profitable at a lower over cost than in the EU. Besides, a Chinese carbon regulation could happen in the next few years; different designs of carbon market are currently tested in five Chinese cities ${ }^{9}$.

And the carbon price plays a key role in CCS profitability and thus its deployment (GIOVANNI E. et al., 2010). Indeed, if there is a carbon regulation, decision makers for power plants would face this choice: either they invest in a CCS power plant to reduce their $\mathrm{CO}_{2}$ emissions and then their carbon burden, or they decide not to install CCS and pay for every ton of $\mathrm{CO}_{2}$ emitted by the power plant. The higher the $\mathrm{CO}_{2}$ price, the higher the interest of CCS investment. But this implies the existence of a $\mathrm{CO}_{2}$ cost pass through to electricity prices. It exists in Europe (SIJM J. et al., 2006 and JOUVET P.-A. et al., 2013) but is currently impossible in China because of regulated electricity prices. Nonetheless, reforms are currently undergone to partly deregulate gas prices (IEA, 2012b); thus an electricity reform is perfectly conceivable.

This context reveals a degree of political voluntarism on part of China, but the question is: will it be turned into a wide CCS deployment in the next few years?

The European Parliament has recently adopted the back-loading proposal, which could be seen as the first step to further structural measures to revitalize the EU-ETS. In the United States, at Barack Obama's request (Climate Action Plan), the Environmental Protection Agency (EPA) released in September 2013 its proposed Clean Air Act standards to significantly reduce $\mathrm{CO}_{2}$ emissions from new coal power plants (CCS will be required): a carbon binding regulation could be implemented in the near future. These recent measures show that policy makers and investors should keep in mind the idea of a possible future carbon regulation/legislation when they make their investment decisions.

Power plant costs strongly differ from China to the EU. Therefore, one can expect that CCS costs vary a lot between China and the EU. Two questions arise: how much is the extra-cost of a CCS plant in the EU in comparison with China? And then, what is the $\mathrm{CO}_{2}$ price beyond which CCS power plants become more profitable than power plants without CCS, in the EU and in China?

To answer these two questions, I carry out a literature review on public studies about technoeconomic CCS costs in the EU and China. CCS cost studies necessarily employ a large set of technical and economic assumptions that can dramatically affect results (RUBIN E. et al., 2007). This paper summarizes the results of the most recent public studies of current CCS costs for fossil fueled power plants and gives an updated and objective comparison of coal and gas power plants with and without CCS, covering a range of assumptions for key parameters. To assess objectively the profitability of a CCS power plant,

\footnotetext{
${ }^{8}$ Alstom, for instance, has namely been involved in these pilots: Lacq (France), Le Havre (France), the Technology Center Mongstad (TCM) (Norway) which is the world's largest facility for testing $\mathrm{CO}_{2}$ capture, or the White Rose project (United Kingdom (UK)).

${ }^{9} 7$ cities are scheduled.
} 
two key metrics are calculated: the Levelised Cost of Electricity (LCOE) and the $\mathrm{CO}_{2}$ switching price (the $\mathrm{CO}_{2}$ price beyond which a CCS power plant becomes more profitable than another power plant type). In other words, I build a net present value model that take into account the $\mathrm{CO}_{2}$ price in order to calculate the breakeven $\mathrm{CO}_{2}$ price. If techno-economic studies on $\mathrm{CO}_{2}$ capture from power generation are numerous in OECD countries, particularly in EU, they are scarce in China (WU N. et al., 2013). But they have in common the fact that very few of them assess the $\mathrm{CO}_{2}$ switching price. My study fills these gaps by providing an objective CCS cost comparison in the EU and in China, and by giving implications for European and Chinese power plant investors/policy makers.

Section 1 gives the state of art about CCS techniques in the power sector, then, section 2 describes the methodology used to draw an economic panorama of CCS power plants, and section 3 presents the main results. In section 4, sensitivity analysis are run, and in section 5, CCS costs by 2030 are assessed to advise investors on the optimal power plant type choice depending on the $\mathrm{CO}_{2}$ market price, and suggest an optimal timing for CCS investment in the EU and China.

\section{State of art: CCS and electricity generation}

\subsection{CCS techniques readiness}

As their name suggests, CCS techniques are a 3 links chain: carbon capture, carbon transport and carbon geological storage.

The $\mathrm{CO}_{2}$ capture is already performed as part of the standard process in some industries: natural gas processing, chemical production, coal gasification, coal to liquid, synthetic natural gas, fertilizer production, hydrogen production and ethanol production. However, capturing $\mathrm{CO}_{2}$ emissions from fossil fuel power plants, blast furnaces or cement kilns has not been deployed yet because their flue gases have low carbon content. Flue gases are a mixture of $\mathrm{CO}_{2}$ but also oxygen, water vapor, or nitrogen. Thus, depending on the industry concerned, the carbon content varies from a few percentage points to nearly $20 \%$. For instance, the $\mathrm{CO}_{2}$ content is around $10-12 \%$ for coal plants and only $3-5 \%$ for gas plants. The effort required for $\mathrm{CO}_{2}$ capture is proportional to the purity of the gas stream: $\mathrm{CO}_{2}$ capture is easier and less expensive when flue gases are $\mathrm{CO}_{2}$ rich. Thus, to reduce their $\mathrm{CO}_{2}$ emissions, utilities, cement and steel manufacturers have to develop specific techniques to capture $\mathrm{CO}_{2}$ and move them to demonstration scale. In 2013, the Global CCS Institute has identified 65 LSIPs around the world; only 12 of which are in operation. The 7000 industrial $\operatorname{sites}^{10}$ that could be equipped with CCS (GIEC, 2005) are far away.

Currently, three main processes are being developed to capture $\mathrm{CO}_{2}$ :

- Pre-combustion carbon capture

The carbon contained in the fossil fuel is removed before the combustion process. The problem is tackled at its root.

It's the most complex carbon capture process. The feedstock (coal for instance) is turned into a synthesis gas (mixture of hydrogen $\mathrm{H}_{2}$ and carbon monoxide $\mathrm{CO}$ ). Then, the syngas undergoes the water-gas shift reaction to produce a $\mathrm{H}_{2}$ and $\mathrm{CO}_{2}$-rich gas mixture. The $\mathrm{CO}_{2}$ concentration can range from $15-50 \%$. The $\mathrm{CO}_{2}$ is separated from $\mathrm{H}_{2}$ in a similar way as in post-combustion process ${ }^{11}$. $\mathrm{H}_{2}$ can be used directly (in refineries namely) or as a fuel in combined-cycle gas plant (electricity or heat without $\mathrm{CO}_{2}$ ) or to produce synthetic fluids.

\footnotetext{
${ }^{10} \mathrm{CO}_{2}$ emissions higher than $100000 \mathrm{t} /$ year.

${ }^{11}$ In the post-combustion process, the flue gas stream is at low pressure and with a low $\mathrm{CO}_{2}$ content $(5-15 \%)$. In the pre-combustion process, the shifted synthesis gas stream is rich in $\mathrm{CO}_{2}$ and at higher pressure; so the $\mathrm{CO}_{2}$ removal is easier.
} 
Pre-combustion capture technology is only applicable to new fossil fuel power plants (Integrated Coal Gasification Combined cycle or IGCC) because the capture process requires significant modifications of the power plant.

- Oxy-combustion carbon capture

In traditional fossil fuelled power plants, combustion is carried out by using air; the flue gas has a low $\mathrm{CO}_{2}$ content so it is costly to separate it. In the oxyfuel process, the combustion is preformed with enriched or high purity oxygen streams; as a result, the flue gas contains only steam and $\mathrm{CO}_{2}$ with a high concentration (greater than $90 \%$ by volume). These two components are then easily separated through cooling; the water condenses and a $\mathrm{CO}_{2}$ rich gas-stream is formed.

Oxy-combustion is sometimes presented as the most promising carbon capture process; innovations are expected to reduce the cost of pure oxygen production (chemical looping).

\section{- Post-combustion carbon capture}

The process consists in separating and removing the $\mathrm{CO}_{2}$ diluted in the flue gas produced by the combustion of a fossil fuel. Several options are available. The most common process is absorption which is based on a chemical reaction between $\mathrm{CO}_{2}$ and a suitable chemical, also called an absorbent. The absorbed $\mathrm{CO}_{2}$ is separated from the absorbent through a thermal regeneration process. Typical absorbents that are used today are amines and carbonates. Cryogenic separation, calcium looping and adsorption are the three other processes.

Positioned downstream, the post combustion capture process can be added to existing coal or gas power plants, blast furnaces, cemeteries... or factories that emit large $\mathrm{CO}_{2}$ amounts.

Post-combustion carbon capture is the most mature and widely used process.

Within each of these three main capture categories, there are several pathways using different technologies which may find particular application more favorably in certain climate conditions, locations and fuel types. In 2013, none of those capture processes were used at an industrial scale in the power/cement/steel sector, but in 2014, two large scale projects should be complete: Boundary Dam 3 (Estevan, Canada), the world's first commercial scale post-combustion carbon capture project at a coal fired generating station, and Kemper County (Mississippi), the only IGCC with CCS under construction worldwide.

As for carbon transport and storage, if the American Enhanced Oil recovery (EOR) experience ${ }^{12}$ can provide some information, two main techno-economical uncertainties need to be removed: i) the safety and reliability of geological $\mathrm{CO}_{2}$ storage in deep saline aquifers need to be demonstrated, ii) the availability of technologically accessible and economically feasible viable storage sites.

Thus large scale integrated projects (LSIPS) are required to remove uncertainties and get more precise capital and operating expenditures (cost and contingencies) for the three links.

\subsection{Uncertainty on CCS costs}

As said before, CCS applied to fossil fuel power plants is an emerging technology. Consequently cost data come from CCS pilot and LSIPs (only 12 around the world (GCCSI, 2013)) in operation, and from engineering and feasibility studies. These cost data correspond to First-of-a-Kind (FOAK) ${ }^{13}$ Projects that is to say projects with technologies at early stage of development. From these cost data, up-scaling deduce full scale plant costs taking into account learning effects and economies of scale as well as a different level of contingencies depending on the number of equipments/similar plant type already built. This enables to compute NOAK ( $\mathrm{N}^{\text {th }}$ of a Kind CCS plants) ${ }^{14}$ costs.

\footnotetext{
${ }^{12} 6200 \mathrm{~km}$ pipelines currently handle about $50 \mathrm{Mt}$ of $\mathrm{CO}_{2}$, in a supercritical state, per year (IEA ETSAP, 2010). 4 storage sites (>1MtCO ${ }_{2}$ per year) are currently in operation around the world.

${ }^{13}$ The technology is at an early stage of development/deployment.

${ }^{14}$ The technology is mature.
} 
Thus, economic data for CCS plant remain uncertain. Besides, the literature overview has raised two questions: (1) are studies influenced by the national energy context? (2) how much independent are public studies about CCS costs? Indeed, for the first question, by comparing public studies two discernable trends appear: American studies (WorleyParsons, 2009, 2011 and NETL, 2010a, 2010b) tend to favor gas plants relatively to coal plants and on the contrary, the European study (ZEP, 2011) tends to favor coal plants relatively to gas plants. Are the American studies influenced by the national energy context, the dash for gas linked with the shale gas exploration and development? This might be a bias. Note that like the DECC, the IEA, sometimes criticized for its too optimistic scenarios, has a median position. The second issue, about public studies independence, is raised by two factors: for most studies, cost data sources are kept secret or lack transparency, and a rather high cost data homogeneity is observed after the standardization of several techno-economic parameters and calculation methodologies (for more details, see 3.3.). One can wonder whether these cost data are rather similar because studies refer to one another and eventually use the same data. The cross analysis of bibliographies shows that most studies refer to others (table 1). Consequently, it is pretty hard to conclude about the independency of these public studies.

\begin{tabular}{|c|c|c|c|c|c|c|c|c|c|c|}
\hline $\begin{array}{l}\text { Quotes } \\
\text { Is ' } \\
\text { quoted. } \\
\text { by }\end{array}$ & EPRI & GCCSI & IEA & $\begin{array}{l}\text { Worley } \\
\text { Parsons }\end{array}$ & $\begin{array}{l}\text { DoE- } \\
\text { NETL }\end{array}$ & ZEP & Alstom & NZEC & $\begin{array}{l}\text { WU N.et } \\
\text { al. }\end{array}$ & DECC \\
\hline EPRI & & $X$ & & $X$ & $X$ & $\bar{X}$ & & & $\bar{X}$ & \\
\hline$\overline{\text { GCCSI }}$ & & & & & & 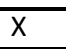 & & & & \\
\hline IEA & & $X$ & & $x$ & & $x$ & $\bar{x}$ & & $\bar{X}$ & $\mathrm{X}$ \\
\hline WorleyP. & & $X$ & & & & $\mathrm{X}$ & & & & $X$ \\
\hline DoE & $x$ & $x$ & $x$ & $x$ & & 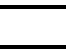 & & & $x$ & \\
\hline ZEP & & $x$ & & & & & & & $x$ & $x$ \\
\hline Alstom & & & & & & $x$ & & & & $x$ \\
\hline NZEC & & & $\mathrm{X}$ & & & & & & $X$ & \\
\hline \multicolumn{11}{|l|}{ WU N.al. } \\
\hline \multicolumn{11}{|l|}{$\overline{D E C C}$} \\
\hline IPCC & & $\bar{X}$ & $\mathrm{X}$ & & & & & & $\bar{X}$ & \\
\hline Rubin & & $\bar{x}$ & $x$ & $x$ & $\bar{x}$ & $x$ & $\bar{x}$ & & $x$ & $\bar{x}$ \\
\hline IEA-GHG & & $\bar{x}$ & $x$ & & $\bar{x}$ & & & & & \\
\hline
\end{tabular}

Table 1: Cross analysis of studies' bibliographies

\section{Methodology and data}

In order to assess more precisely the potential of CCS as a key option for climate change mitigation, this study aims at reviewing, analyzing and comparing public studies in the purpose of drawing an objective techno-economic panorama of CCS applied to the power sector in the EU and in China. It implies: (1) studying the profitability of CCS plants respect to power plants without CCS (marginal economic analysis), (2) assessing the costs and performance of carbon capture techniques - precombustion, oxy-combustion, post-combustion - to indicate which one is the most profitable, (3) determining the $\mathrm{CO}_{2}$ price beyond which CCS power plants become more profitable than non-CCS power plants also called reference coal plants.

To perform th is comparative analysis of CCS costs and assess the profitability of these techniques the following methodology is employed: 
- Literature review to select the most recent and relevant individual techno-economic studies ${ }^{15}$.

- Calibration of economic data (discount rate, currency, fuel cost...) and calculation methodologies (capital cost...) for the selected studies.

- Standardized calculation of two key metrics: the $\mathrm{LCOE}$ and the $\mathrm{CO}_{2}$ switching price (see below).

- Data analysis and result discussions.

- Conclusions and recommendations.

\subsection{Two key metrics to assess CCS power plant profitability}

CCS techniques will be deployed if and only if they are a profitable option for industrials/investors. CCS power plant profitability is directly linked to CCS extra-costs. These are of two kinds:

- Fixed: at the start of the project ${ }^{16}$,

- Variable: during the operation time ${ }^{17}$, because of:

- Net efficiency penalties (from 8 to 10 points) which means higher fuel consumption.

- Higher operating and maintenance expenditure.

The extra-costs induced by CCS devices are assessed through the two following key metrics:

- The Levelised Cost of Electricity (LCoE).

The LCoE is equal to the minimum selling price of electricity for which the power plant becomes profitable (the NPV is null). It is a uniform annual value giving the same net present value as the year-by-year case. The LCoE is expressed in $€ / M W h$ and is equal to the present value of the sum of discounted costs divided by total production adjusted for its economic time value ${ }^{18}$.

- The $\mathrm{CO}_{2}$ switching price ${ }^{19}$.

When the $\mathrm{CO}_{2}$ price is not null, power plants without $\mathrm{CCS}$ are significantly charged for their $\mathrm{CO}_{2}$ emissions on the contrary to CCS power plants. So there exists a $\mathrm{CO}_{2}$ price that equals the $\mathrm{LCOE}$ of CCS and non-CCS power plants. In other words, there exists a $\mathrm{CO}_{2}$ price beyond which CCS power plants become more profitable than the same plants without $\operatorname{CCS}^{20}$ (Figure 1). It also can be seen as the $\mathrm{CO}_{2}$ price for which the NPV of the differential project (NPV CCS - NPV ref) is null.

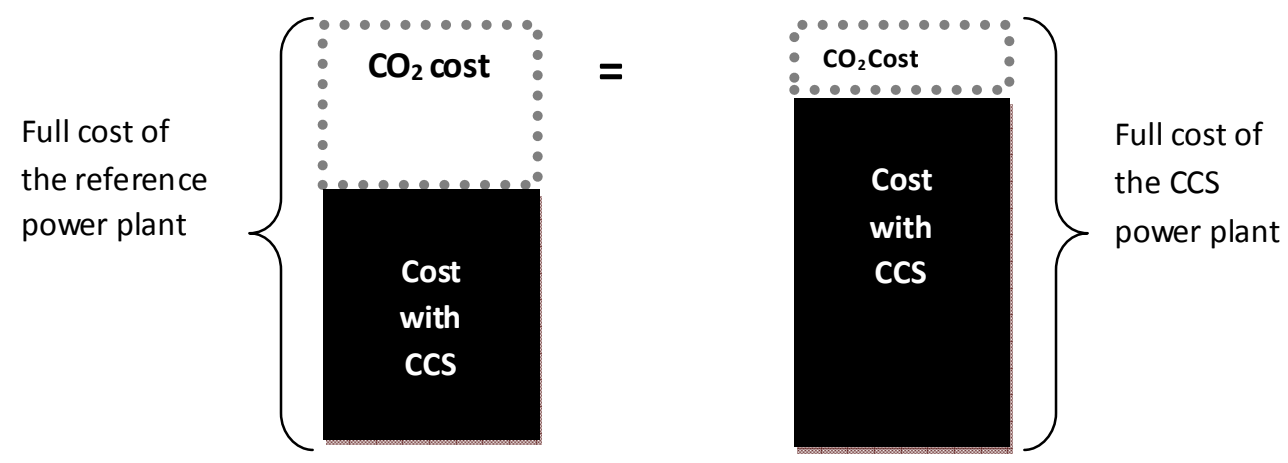

Figure 1: The $\mathrm{CO}_{2}$ switching price concept

\footnotetext{
${ }^{15}$ Public studies.

${ }^{16}$ One can also speak about CAPEX (CAPital EXpenditure).

${ }^{17}$ One can also speak about OPEX (OPerating EXpenditure).

${ }^{18}$ With my simplifying assumptions (costs constant with time), the LCOE is: $\frac{\text { Constant Investment Annuity }+ \text { O\&M cost }+F u e l \text { cost }+ \text { Carbon cost }}{\text { Electrictyproduction }}$.

${ }^{19} \mathrm{CO}_{2}$ switching price $=\frac{\text { Constant Investment Annuity }{ }^{A} \text {-Constant Investment Annuit }{ }^{B}+O \& M \operatorname{cost}^{B}-O \& M \operatorname{cost}^{A} \text { Fuel cost }^{B}-F_{u e l} \text { cost }^{A}}{\text {. }}$.

${ }^{20}$ Also called reference plants.
} 
It can be noticed that there is still a $\mathrm{CO}_{2}$ cost box for the CCS power plant. Indeed, the carbon capture rate is $90 \%$ not $100 \%$.

These two key metrics will allow us to establish a merit order between CCS and non-CCS power plant $\mathrm{LCOEs}$ according to different $\mathrm{CO}_{2}$ price scenarios.

\subsection{Public studies selection and scope of analysis}

The public studies selected in this paper are the following: IEA (2010, 2011, 2012b, 2012d), Alstom (2011), DECC (2012, 2013), Global CCS Institute (2011, 2013), ZEP (2011a, 2011b, 2011c), NETL (2010a, 2010b) WorleyParsons (2009, 2011), NZEC (2009) and WU N. et al. (2013).

These studies have been selected because they are considered as references in the "CCS sphere" and were published over the last five years. Noteworthy is the suggestion made by the Global CCS Institute (GCCSI, 2011) at public studies that recently showed significant increase of CCS costs: "The levelised cost estimates in the studies [NETL, WorleyParsons, IEA, ZEP] are consistently higher than those estimated three or more years ago. Due to changing methodologies and the inclusion of previously omitted items, costs are now suggested to be 15 to 30 per cent higher than earlier estimates" (p66).

This study focuses on:

- new-built large-scale base-load operating coal and gas plants (more than $350 \mathrm{MW}$ ),

- mature CCS techniques (not pilot projects). Thus, provided costs are not relative to FOAK ( $\mathrm{F}^{\text {st }}$ Of A Kind) power plants. The cost data provided by the public studies used in this paper are for 2015-2020.

It as to be said that cost data presented in this study do not intend to represent the costs of specific projects, but try to indicate a global trend.

- capture techniques whose capture rate is larger than $85 \%$.

\subsection{How can techno-economic information from different studies been turned into a comparable set} of data?

As previously said, most studies have their own methodology to calculate economic data such as the capital cost, the LCOE... Moreover, there is not a set of commonly agreed on boundary conditions such as the discount rate, the fuel cost... As a consequence, it is very tricky to compare straightforward CCS cost data from different studies. Indeed, the LCoE is very sensitive to parameters such as the plant efficiency, the fuel price, the discount rate... (Figure 2).

Figure 6 . Impact of a $\pm 50 \%$ variation in key assumptions on LCOE

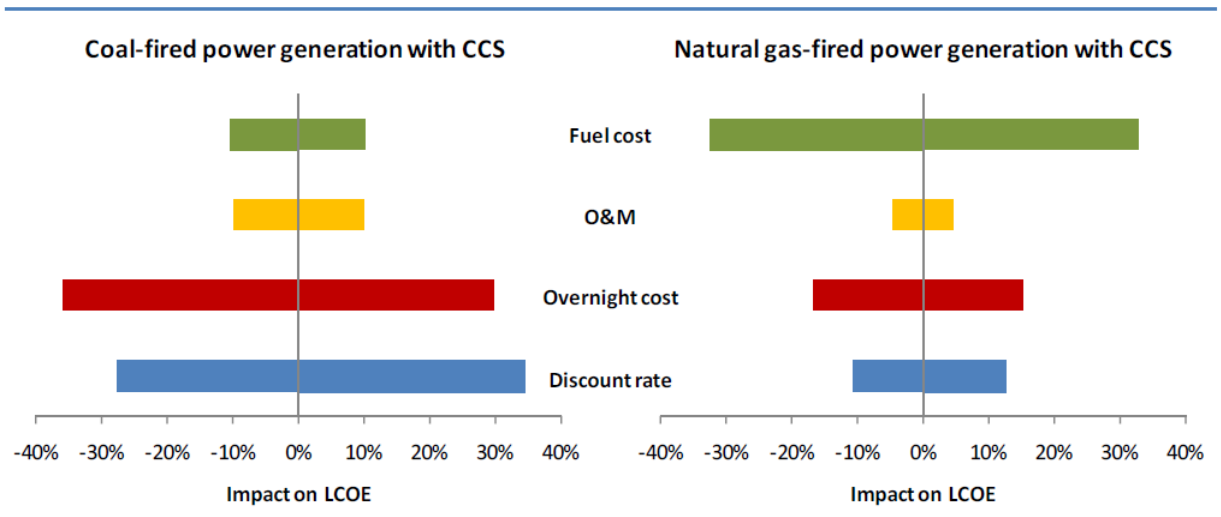

Figure 2: LCoE sensibility to key parameters (From IEA, 2011) 
To address this issue and objectively compare $\mathrm{LCOE}$ and $\mathrm{CO}_{2}$ switching prices from different studies, only 4 data are kept from the selected public studies: Overnight cost ${ }^{21}$, Operating and maintenance costs, $\mathrm{CO}_{2}$ emission factor and net power (table 2).

Several techno-economic parameters (table 4) and calculation methodologies (table 3) are standardized.

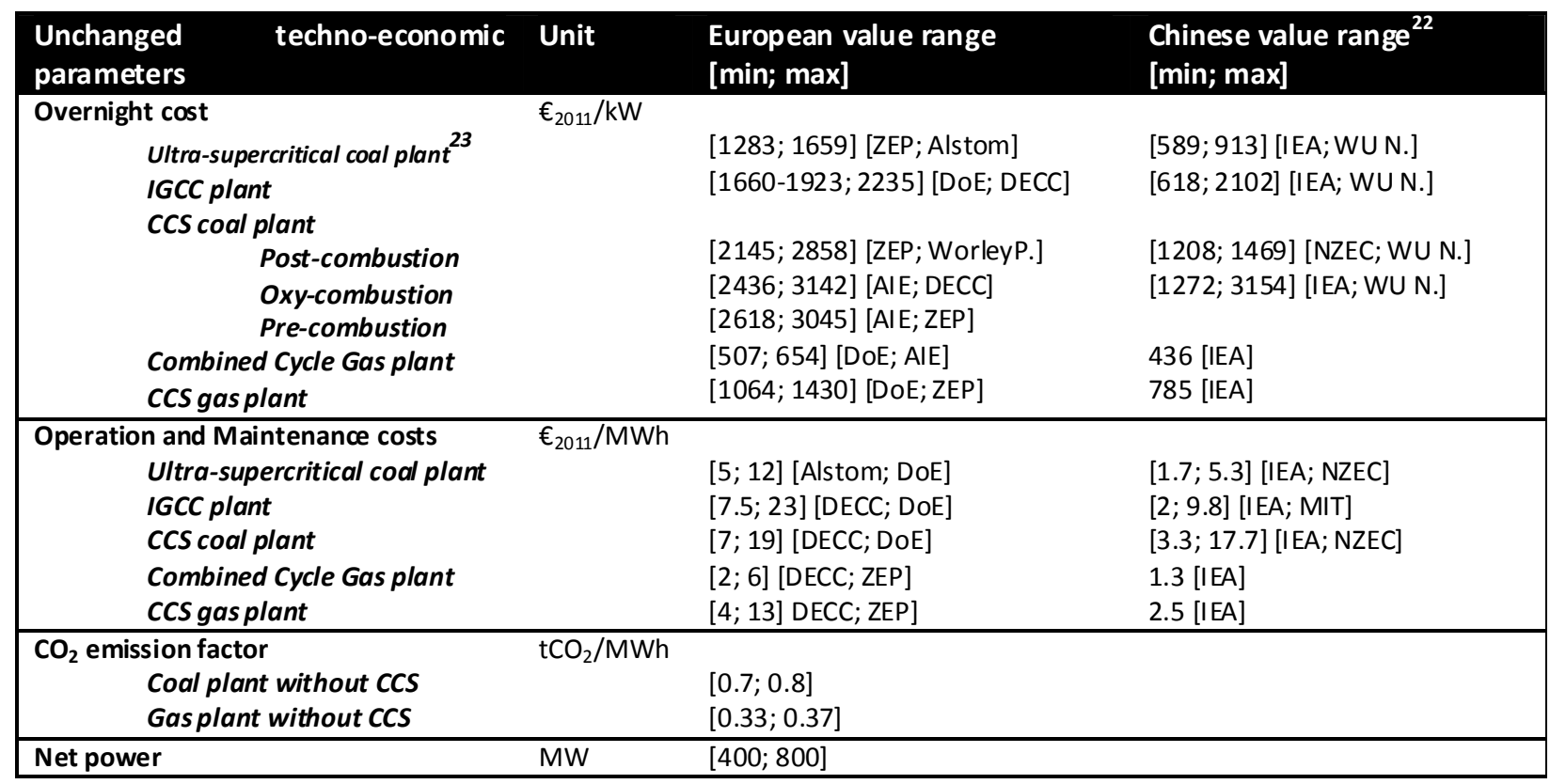

Table 2: Unchanged techno-economic parameters

\begin{tabular}{|lll|} 
Calculation methodology & $\begin{array}{l}\text { Applied to studies since the } \\
\text { beginning }\end{array}$ & $\begin{array}{l}\text { Applied to studies at the } \\
\text { standardization time }\end{array}$ \\
\hline $\mathrm{CO}_{2}$ emission factor & $\mathrm{X}$ & $\mathrm{X}$ \\
\hline Constant investment annuity ${ }^{24}$ & $\mathrm{X}$ & $\mathrm{X}$ \\
\hline $\mathrm{LCoE}^{\mathrm{CO}}$ & $\mathrm{X}$ & $\mathrm{X}$ \\
\hline $\mathrm{CO}_{2}$ switching price & $\mathrm{X}$ & $\mathrm{X}$ \\
\hline Fuel cost & & $\mathrm{X}$ \\
\hline
\end{tabular}

Table 3: Standardized calculation methodologies

\footnotetext{
${ }^{21}$ IDC are calculated in a very simplified way. Let's assume that the construction time is 4 years and that the life time is 20 years. The annuity is levelised from year 4 to 23 instead of 0 to 19 . It means that during the four first years the power plant pays interests and starts its production from the fourth year. Some studies, the ZEP's one for instance, provide capital costs with IDC and/or owners' costs. It implies the recalibration of capital costs by subtracting IDC and/or owner's costs. Note that net power outputs are unchanged. Indeed, studies might take into account scale effects.

${ }^{22}$ Only three studies analyze Chinese CCS costs: NZEC (2009), IEA (2010), WU N. et al. (2013).

${ }^{23}$ I divide into ultra-supercritical coal plants and IGCC plants for IGCC remain little used (there are less than 10 IGCC around the world and the technology is still a demonstration and experimental stage) and have different investment and operating and maintenance costs. IGCC can only be fitted on pre-combustion capture.

${ }^{24}$ PARK Chans S. [Analyse économique en ingénierie, Editions du renouveau pédagogique, 2009, p63-64] gives:

Constant Investment Annuity $=\frac{\text { Investment }}{\sum_{k=0}^{n} \frac{1}{(1+\text { discoun } r \text { tae })^{k}}}[1]$ so: Constant Investment Annuity $=\quad$ Total Plant Cost $(€ / \mathrm{kW}) \times 1000 *$ 8760 hours $\times$ Capacity Factor $(\%) * \sum_{k=0}^{n} \frac{1}{(1+\text { discoun rtae })^{k}}$ [2]
} 


\begin{tabular}{|c|c|c|c|}
\hline $\begin{array}{l}\text { Standardized techno-economic } \\
\text { parameters }\end{array}$ & Unit & European values & Chinese values \\
\hline \multicolumn{2}{|l|}{ Currency $^{25}$} & \multicolumn{2}{|l|}{$€_{2011}$} \\
\hline Capacity factor & $\%$ & \multicolumn{2}{|l|}{85 [7 446 hours/yr] = BASE } \\
\hline Capture rate & $\%$ & \multicolumn{2}{|l|}{$90^{26}$} \\
\hline \multicolumn{2}{|l|}{ Plant efficiency } & \multirow{2}{*}{\multicolumn{2}{|c|}{$\begin{array}{l}\text { [9pts of penalty] } \\
45 \%(2015)\end{array}$}} \\
\hline \multirow{2}{*}{ CCS coal plant } & $\%$ & & \\
\hline & $\%$ & \multicolumn{2}{|l|}{$\begin{array}{l}\text { [8pts of penalty] } \\
60 \%(2015)\end{array}$} \\
\hline Gas plant & $\%$ & $60 \%(2015)$ & \\
\hline CCS gas plant & $\%$ & \multicolumn{2}{|l|}{$52 \%(2015)$} \\
\hline \multicolumn{4}{|l|}{ Construction time } \\
\hline Coal plant (PCI) & years & \multicolumn{2}{|l|}{4} \\
\hline CCS coal plant & years & \multicolumn{2}{|l|}{5} \\
\hline Gas plant & years & \multicolumn{2}{|l|}{2} \\
\hline CCS gas plant & years & \multicolumn{2}{|l|}{3} \\
\hline \multicolumn{4}{|l|}{ Lifetime } \\
\hline Coal plant & years & \multicolumn{2}{|l|}{40} \\
\hline Gas plant & years & \multicolumn{2}{|l|}{25} \\
\hline \multicolumn{4}{|l|}{ Fuel price $^{27}$} \\
\hline Black coal (Illinois $\left.n^{\circ} 6\right)$ & $\$ 2011 / G J$ & \multirow{2}{*}{$\begin{array}{l}\text { 2015: } 4.34(108.5 \$ / t) \\
2015: 11.61(11 \$ / M B t u)\end{array}$} & 2015: $3.8(95 \$ / t)$ \\
\hline Natural gas & $\$ 2011 / G J$ & & 2015: 10.55 (10 \$/MBtu) \\
\hline $\mathrm{CO}_{2}$ price & $€ / \mathrm{t}$ & \multicolumn{2}{|l|}{0} \\
\hline Owner's cost $^{28}$ & Overnight cost \% & \multicolumn{2}{|l|}{15} \\
\hline Discount rate [real and after tax] & $\%$ & \multicolumn{2}{|l|}{8} \\
\hline Transport costs ${ }^{29}$ & $€_{2011} / \mathrm{MWh}$ & Off-shore: 5.8 & $\begin{array}{l}\text { On-shore: } 1.35 \\
\text { Off-shore: } 4.35\end{array}$ \\
\hline \multicolumn{2}{|c|}{$\begin{array}{l}\text { Deep saline aquifer. Mid scenario (ZEP, } \\
\text { 2011c). }\end{array}$} & Off-shore : 8.7 & $\begin{array}{c}\text { On-shore: } 3.45 \text { (coal)/ } \\
1.8 \text { (gas) } \\
\text { Off-shore: } 6.5 \\
\end{array}$ \\
\hline
\end{tabular}

Table 4: Standardized techno-economic parameters

Note that carbon transport and storages costs come from ZEP's reports (2011b and 2011c). Indeed, the ZEP is considered as a reference ${ }^{30}$ and has provided very well detailed reports that distinguish onshore and offshore carbon transport and storage costs, for coal and gas plants. Indeed, it seems that the EU has mostly off-shore storage capacities, whereas China would have both (DAHOWSKI R.T. et al., 2009). There are still great uncertainties about storage potentials because of the lack of detailed site characterization studies.

\footnotetext{
${ }^{25}$ Cost data are calibrated to 2011 cost levels by using cost indices (Price index Consumer from http://stats.oecd.org/, Eurostat, Oxford Economic (Forecast) and Asia Pacific Consensus Forecast (April 2013)). Then cost data are converted from the original currency to EUR $\mathrm{R}_{2011}$. Exchange rates are from $\mathrm{OECD}$ stat.

${ }^{26}$ According to public studies, the $\mathrm{CO}_{2}$ capture rate ranges from $70 \%$ (Alstom, 2011, for gas) to $95 \%$ (AIE, 2010, oxy-combustion capture on a gas plant). A $90 \%$ value is chosen because it is the most widely used value (DoE-NETL, WorleyParsons, IEA and ZEP).

${ }^{27}$ Standardizing fuel prices means that fuels are homogeneous. Comparability between studies is higher. European fuel price hypothesis come from the World Energy Outlook 2012 (IEA, 2012c). Chinese fuel price assumptions come from the comparison of several studies (bibliography). Indeed, there are no official fuel prices in China, for prices are partly/totally administered.

${ }^{28}$ Owners' costs are calculated as a fraction of the overnight cost. According to studies, owners' costs range from $5 \%$ (EPRI) to $25 \%$ (DoE-NETL). A $15 \%$ value is chosen. It takes into account a risk premium.

${ }^{29}$ On-shore: $180 \mathrm{~km}$ pipe. For a single CCS coal plant (2X700 MW), $\mathrm{CO}_{2}$ transported: $10 \mathrm{Mtpa}$, for a single CCS gas plant: $2.5 \mathrm{Mtpa}$. Off-shore: $500 \mathrm{~km}$ pipe +feeders + Distribution pipeline. Cluster of CCS coal $(3 \times 700 \mathrm{MW})$ and CCS gas $(2 \times 360 \mathrm{MW})$ plants. $\mathrm{CO}_{2}$ transported: 20 Mtpa. Mid scenario.

${ }^{30}$ For example, DECC's report (2012) writes: the ZEP's "review of transport costs provides the most recent and in our opinion reliable general assessment". Idem for storage costs.
} 
This standardization process allows a rigorous calculation and comparison of $\mathrm{LCoEs}$ and $\mathrm{CO}_{2}$ switching prices between studies. After this standardization, cost data from studies are less heterogeneous. Across studies, LCoE values could:

- Range from 30 to $75 \%$ for a specific coal power plant type (Figure 3),

- Reach $75 \%$ for a specific post-combustion gas plant type.

After the standardization, it has been observed that LCoEs:

- Range from 12 to $25 \%$ for a specific coal power plant type (Figure 3),

- Range 0 to $15 \%$ for a specific post-combustion gas plant type.

This higher homogeneity in cost data is in accordance to the GCCSI (2011): "The different cost estimates observed in the various studies arise due to differences in assumptions regarding technology performance, cost of inputs or the methodology used to convert the inputs into levelised costs. Many of these differences disappear when the assumptions are normalized and a common methodology is applied".

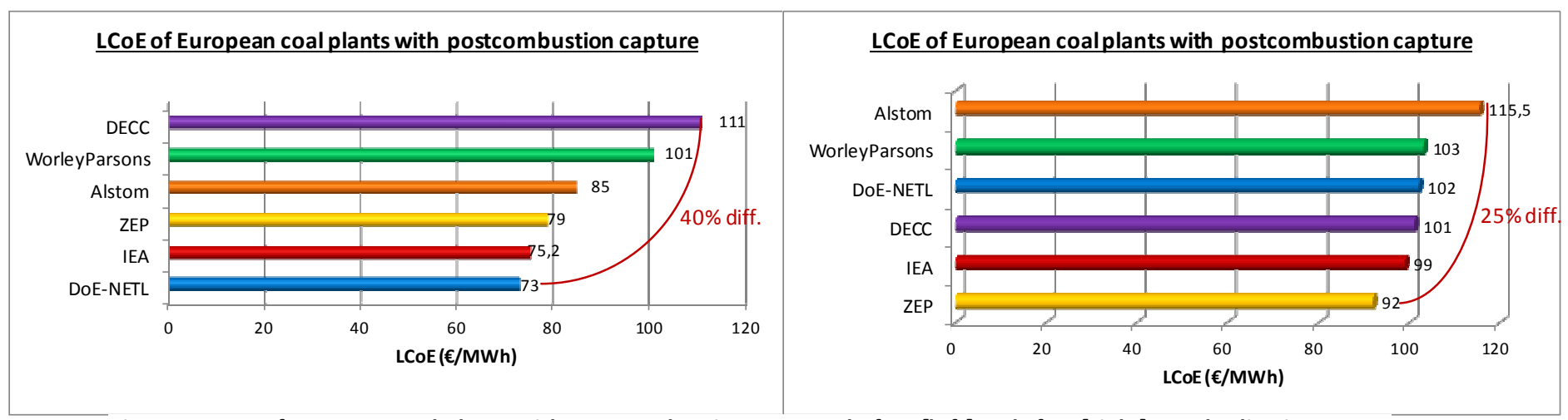

Figure 3: LCoE of European coal plants with post-combustion capture, before [left] and after [right] standardization. Transport and storage costs are not included.

LCoE residual differences between studies for a specific power plant type are mainly due to discrepancies in O\&M assumptions (they can vary substantially by a factor of more than 2 or 3). For instance, LCoE residual differences are reduced by $70 \%$ when IEA O\&M assumptions are applied.

\subsection{Chinese cost calculation}

Only very few studies compare CCS costs in China: the NZEC's study (2009), the IEA's (2010) and the WU N. et al.'s (2013). In fact, there are many studies about Chinese IGCC and ultra-supercritical coal plant cost comparison, but they neither consider $\mathrm{CCS}$ nor the $\mathrm{CO}_{2}$ price beyond which a particular kind of power plant become profitable regarding other kinds of power plants.

However, by using cost location factors, it is possible to assess CCS costs in China. Indeed, WorleyParsons (2011) has defined cost location factors ${ }^{31}$ using data from Richardson Products' International Cost Factor Location Manual 2009-2010 Edition. Richardson is usually considered as the reference in the field of regional cost indices. Thus this study uses cost location factors ${ }^{32}$ from WorleyParsons' study (Table 5).

\footnotetext{
31 "To support conversion of the reference case costs from USGC [US Gulf Coast] to location specific costs (expressed in US dollars) for the selected cities/countries, conversion indices were developed for three major cost elements. These include imported equipment and materials, locally sourced equipment and materials, and labour."

${ }^{32}$ When data costs refer to European power plants [ZEP, Alstom, DECC], I apply the cost location factor to move a power plant from Europe to the USGC and then I apply the cost location factor to move the plant from the USGC to China. Note that for the NZEC's study, I only convert cost data from $\mathrm{CNY}_{2009}$ to $\mathrm{EUR}_{2011}$. Cost location factors can be applied straightforward for two studies: DoE-NETL's and WorleyParsons'. Indeed, in
} 


\begin{tabular}{llll}
\hline & & Capital and O\&M Costs $^{33}$ \\
\hline Region & Equipment & Materials & Labor \\
United States (USGC) & 1 & 1 & 1 \\
Europe (Euro Region) & 1.19 & 1.16 & 1.33 \\
China & 0.81 & 0.81 & 0.05 \\
\hline
\end{tabular}

Table 5: Regional indices used to transfer projects from USGC to specific locations

Note that cost location factors cannot be used to turn European carbon transport and storage costs into Chinese costs. Indeed, the ZEP provides aggregated data: CAPEX and OPEX. Thus the relative share of equipment, materials and labor is unknown. To get Chinese carbon transport and storage costs, the following ratio is applied: Purchasing Power Parity $€_{€ / R M B} /$ Market Exchange rate $_{R M B / €}$. With 2013 OECD data, a value of 0.75 is obtained. In the absence of reliable Chinese information about Transport and Storage (T\&S) costs, a reduction of $25 \%$ is applied to European costs.

Thanks to this cost location factor approach, CCS costs in China can be assessed through 8 studies instead of 3 . So this study fills the current gap by providing and comparing CCS costs data in China.

\section{Economic panorama of CCS power plants}

The results of the calculation and interpretation of the two key metrics, $\mathrm{LCoE}$ and $\mathrm{CO}_{2}$ switching price, are presented below.

\subsection{None of the carbon capture techniques have a clear cost advantage}

For gas plants, only one carbon capture technique is studied: post-combustion capture. Note that if all OECD studies analyze CCS gas plants, only one of the three studies about Chinese CCS costs analyzes CCS gas plants: IEA (2010). It's hardly surprising. Indeed, in 2010, gas power plants generated only $2 \%$ of the Chinese electricity. In 2015, their share could rise to 3.5\% (IEA, 2012b).

For coal plants, none of the carbon capture techniques have a clear cost advantage ${ }^{34}$. This observation is shared by the Global CCS Institute (2011, p66): "Given the uncertainties, at this stage, it is difficult to identify any single technology with a clear cost advantage". Although post-combustion capture techniques do not have a clear cost advantage, they should be the first to be deployed at a commercial scale for they are the most mature. Pre-combustion capture only concerns IGCC plants which are still few and at the FOAK stage. Oxy-combustion capture seems to be a promising technique but still needs research and development efforts to reduce energy consumption for the oxygen production (chemical looping could be part of the solution).

these two studies, the Labour/Equipment/Raw Materials items clearly appear. But the ZEP, DECC and Alstom studies, provide global/concatenated investment and O\&M cost data. Thus, thanks to DoE and WorleyParsons' studies, an allocation key [one for investment cost and one for O\&M costs] has been determined and then applied to ZEP, Alstom and DECC's studies. Cost location factors are applied to studies after the standardization (see 3.3.).

${ }^{33}$ These factors remain constant over the time which might be a limitation of this study and could give further developments.

${ }^{34}$ For The EU: for ZEP, the capture technique which have the lowest LCOE is post-combustion for ZEP (92 €/MWh), pre-combustion for the IEA (98€/MWh), and oxy-combustion for the DECC, WorleyParsons and Alstom (that doesn't study pre-combustion capture) (respectively 95,97 and $109 € / \mathrm{MWh}$ ). Note that the DoE-NETL doesn't study oxy-combustion capture and doesn't give a clear rank between carbon capture techniques. Rankings are exactly the same for China. Indeed, Chinese CCS costs are directly given by 3 studies (NZEC, IEA, WU N. et al.) and derived from 5 US or European studies (ZEP, Alstom, DoE, WorleyParsons, DECC) through cost location factors. Thus, for China too, it is not possible to identify one carbon capture technique with a clear cost advantage. $\mathrm{T} / \mathrm{S}$ costs are not included here. 


\subsection{Extra-costs due to CCS device}

A CCS plant undergoes an increase in both investment and O\&M costs.

- Fixed costs:

- The coal overnight cost increases on average by $70 \%$ in Europe vs $60 \%$ in China.

- The gas overnight cost increases on average by $110 \%$ both in Europe and China.

- Variable costs:

- Net efficiency penalties of 9 percentage points for coal plants vs 8 points for gas plants which imply an increase of respectively $25 \%$ vs $15 \%$ in fuel costs.

- O\&M costs increase on average by $80 \%$ for coal plants and $100 \%$ for gas plants.

By adding carbon capture, coal LCoE increases on average by $60 \%$ (onshore T\&S costs) or $74 \%$ (offshore T\&S costs) in China (respectively 63 and $70 € / \mathrm{MWh}$ ) vs by $80 \%$ in European countries (106 €/MWh). Chinese LCoEs for CCS coal plants are 43 to $35 € / M W h$ lower than European's.

By adding carbon capture, gas LCoE increases on average by $30 \%$ (onshore T\&S costs) or $44 \%$ (offshore T\&S costs) in China (respectively 75 and $83 € / \mathrm{MWh}$ ) vs $55 \%$ in European countries (104 €/MWh). As a result, Chinese LCoEs for CCS gas plants are 29 to $21 € / M W h$ lower than European.

\section{3. $\mathrm{CO}_{2}$ price and breakeven point}

Chinese $\mathrm{CO}_{2}$ switching price are almost twice as low than European.

CCS coal power plants become more profitable than reference coal plants beyond an average $\mathrm{CO}_{2}$ price estimated in China to $33 € / t$ with onshore carbon transport and storage costs and to $42 € / t$ with offshore transport and storage costs, vs $67 € /$ t for European countries ${ }^{35}$.

CCS gas power plants become more profitable than reference gas plants beyond an average $\mathrm{CO}_{2}$ price estimated to $55 € / t$ (onshore T\&S costs) or $82 € / t$ (offshore T\&S costs) for China vs $115 € / t^{36}$ for European countries.

3.4. The investor's vision on CCS: depending on the $\mathrm{CO}_{2}$ price, in which power plant type invest?

Until now, I have calculated intra-technique $\mathrm{CO}_{2}$ switching price (CCS coal plant vs reference coal plant// CCS gas plant vs reference gas plant). However, in practice, whatever the $\mathrm{CO}_{2}$ price, an investor will compare all the possible arbitrations: reference coal plant vs reference gas plant, reference coal plant vs CCS gas plant, reference gas plant vs CCS coal plant and as seen before, reference coal plant vs CCS coal plant and reference gas plant vs CCS gas plant. Then he will choose the power plant with the lowest $\mathrm{LCOE}$. The power plant type with the lowest $\mathrm{LCOE}$ varies with the $\mathrm{CO}_{2}$ price.

Arbitrations in bold correspond to inter-technique $\mathrm{CO}_{2}$ switching price, the others to intra-technique $\mathrm{CO}_{2}$ switching price. Inter-technique $\mathrm{CO}_{2}$ switching price are absent from CCS literature. By taking into account all the possible arbitrations, intra and inter-technique $\mathrm{CO}_{2}$ switching prices better represent the complex reality of an investor.

Results vary a lot between European countries and China. Thus, I'll first study Europe, then China and finally, I'll quickly compare them.

\footnotetext{
${ }^{35}$ It is in accordance with the specialized literature. Offshore storage costs.

${ }^{36}$ It ranges from $91 € / t$ (IEA) to 137 (ZEP).
} 


\subsubsection{In European countries}

\section{When the $\mathrm{CO}_{2}$ price is low (less than $20 € / \mathrm{t}$ )}

Coal and gas reference power plants are the most competitive, that is to say they have the lowest LCOE. Then, the main decisive factors for investment are relative fossil fuel prices. It echoes the "fuel switch" concept.

What happened in Europe a few months ago is a good illustration. Indeed, because of the shale gas exploration, the United States have increased their coal exportations to Europe. Thus, the European coal price has become even lower than the gas price. Moreover, the European $\mathrm{CO}_{2}$ price is less than $5 € / t$. Thus, coal plants have increased their competitiveness compared to gas plants. As a consequence, in April 2013, GDF Suez mothballed three out of four CCG: two for summer time (Combigolfe and Spem) and one for indeterminate period (Cycofos).

\section{When the $\mathrm{CO}_{2}$ price is more significant: from $20 €$ to $67 € / \mathrm{t}$} plants ${ }^{37}$.

When the $\mathrm{CO}_{2}$ price increases, the carbon burden becomes significant for reference power Beyond $20 € / \mathrm{t}^{38}$, it is more interesting to invest in a gas plant than in a coal plant.

This coal to gas $\mathrm{CO}_{2}$ switching price is highly sensitive to fossil fuel prices (Table 8 in Annex). Ceteris paribus, when the coal price varies by $+/-20 \%$, the $\mathrm{CO}_{2}$ switching price varies more than proportionally by $+/-50 \%$. This switching $\mathrm{CO}_{2}$ price is even more sensitive to gas price: when it varies by $+/-20 \%$, the $\mathrm{CO}_{2}$ switching price varies by $+/-95 \%$.

To summarize, beyond $20 € / \mathrm{tCO}_{2}$ until $67 € / \mathrm{tCO}_{2}$, gas plants are the most profitable power plant type.

\section{When the $\mathrm{CO}_{2}$ price ranges from 67 to $115 € / \mathrm{t}$}

CCS coal plants become more profitable than reference coal plants (relative cost-effectiveness). However, the reference gas plant is still the most profitable power plant type ie they have the lowest LCoE.

\section{When the $\mathrm{CO}_{2}$ price is higher than $115 € / \mathrm{t}$}

CCS power plants are more cost-effective than reference power plants. More precisely, CCS gas plants and not CCS coal plants have the lowest LCoE, except for the ZEP. It could be surprising because the intra-technique $\mathrm{CO}_{2}$ switching price is higher for gas than for coal plants. Recent declarations seem to confirm this result. During the ZEP's Assembly (September 2012), it was said that funding CCS gas pilots was a priority. In England, the Peterhead CCS project is a CCS gas plant.

To summarize, in European countries, the investment choice first depends on the switch induced by fossil fuel prices. Currently, from 0 to $20 € / \mathrm{tCO}_{2}$, coal plants are the most cost-effective power plant type, and from 20 to $115 € / \mathrm{tCO}_{2}$, gas plants become the most profitable. Then, when the $\mathrm{CO}_{2}$ price exceeds $115 € / t$, a second switch, favorable to (gas) CCS power plants, dominates.

\footnotetext{
${ }^{37}$ For instance, with a $\mathrm{CO}_{2}$ price at $40 € / \mathrm{t}$, the $\mathrm{LCoE}$ of reference coal plants increase by $40 \%(+30 € / \mathrm{MWh})$ and the $\mathrm{LCoE}$ of reference gas plants increase by $15 \%(+15 € / \mathrm{MWh})$.

${ }^{38}$ Note that this $\mathrm{CO}_{2}$ switching price varies widely between studies: from $9 €(D E C C)$ to $39 €$ (ZEP). The value indicated is the mean.
} 


\subsubsection{In China}

Two cases need to be distinguished: when carbon transport and storage infrastructures are onshore or offshore.

\section{Onshore carbon transport and storage costs}

When the $\mathrm{CO}_{2}$ price is lower than $33 € / t$, coal plants are the most profitable power plant type. When the $\mathrm{CO}_{2}$ price is higher than $33 € / t, \mathrm{CCS}$ coal plants become the most cost-effective power plant type.

Note that beyond $55 € / \mathrm{tCO}_{2}$, CCS gas plants become more profitable than reference gas plants, but are still less competitive than CCS coal plants.

Thus, in China, the investment choice only depends on the $\mathrm{CO}_{2}$ price. When it is lower than $33 € / t$, reference coal plants are the most profitable power plant type, beyond, these are CCS coal plants.

\section{Offshore carbon transport and storage costs}

For the ZEP (2011) and IEA studies (2011), when the $\mathrm{CO}_{2}$ price is lower than $42 € / t$, coal plants are the most profitable power plant type. When the $\mathrm{CO}_{2}$ price is higher than $42 € / t, C C S$ coal plants become the most cost-effective power plant type.

For the DoE, WorleyParsons and DECC studies, when the $\mathrm{CO}_{2}$ price is lower than $38 € / t$, coal plants are the most profitable power plant type. When the $\mathrm{CO}_{2}$ price is between 38 and $50 € / \mathrm{t}$, gas plants are the most cost-effective power plant type. When the $\mathrm{CO}_{2}$ price is higher than $50 € / t$, CCS coal plants become the most profitable power plant type.

On average, the $\mathrm{CO}_{2}$ price beyond which CCS coal plants become the most profitable baseload power plant is $47 € / \mathrm{t}$.

\subsubsection{China and EU CCS costs comparison}

To conclude, in China, when the carbon transport and storage network is onshore, gas plants, with or without CCS, are never the most profitable option.

When the carbon transport and storage network is offshore, gas plants are the most competitive plant type for a small range of $\mathrm{CO}_{2}$ prices: between 38 and $50 € / \mathrm{t}$. As the lifetime of a gas plant is 25 years vs 40 years for a coal plant, if the $\mathrm{CO}_{2}$ price is expected to rise quickly, gas plants might be less interesting than CCS coal plants or at least CCS ready coal plants.

Thus, it can be said that in China, coal plants, with and without CCS, are almost always the most profitable power plant type.

On the contrary, in European countries, gas plants, without and then with CCS are the most costeffective power plant type beyond $20 € / \mathrm{tCO}_{2}$.

The $\mathrm{CO}_{2}$ switching price beyond which CCS power plants become more profitable than all the other power plant types is $115 € / \mathrm{tCO}_{2}$ in Europe ( $\mathrm{LCOE}$ around $105 € / \mathrm{MWh}$ ) against only $33 € / \mathrm{tCO}_{2}$ in China when the transport and storage network is onshore ( $\mathrm{LCoE}$ around $65 € / \mathrm{MWh}$ ) and $47 € / \mathrm{tCO}_{2}$ when the Chinese network is offshore (LCOE around $70 € / \mathrm{MWh}$ ).

This result is mainly due to lower investment and O\&M costs in China than in European countries and, in a lesser extent, to cheaper raw materials and fuel prices. 


\section{Sensitivity analysis}

I assess the sensitivity of European and Chinese $\mathrm{LCOEs}$ and $\mathrm{CO}_{2}$ switching prices to variations of the standardized techno-economic parameters.

\begin{tabular}{|c|c|c|c|}
\hline $\begin{array}{l}\text { Standardized techno-economic } \\
\text { parameters }\end{array}$ & Unit & Value & Variations \\
\hline Capture rate & $\%$ & 90 & -5 points $(85 \%)$ \\
\hline Load factor $^{39}$ & $\mathrm{Hrs} / \mathrm{yr}$ & & Base load vs Mid load \\
\hline \multicolumn{4}{|l|}{ Construction time } \\
\hline Coal plant & Year & 4 & Coal plant: +1 year \\
\hline CCS coal plant & Year & 5 & \\
\hline Gas plant & Year & 2 & Gas plant : +1 year \\
\hline CCS Gas plant & Year & 3 & \\
\hline \multicolumn{4}{|l|}{ Lifetime } \\
\hline Coal plant & Year & 40 & -5 years \\
\hline Gas plant & Year & 25 & {$[-5$ years; +5 years $]$} \\
\hline \multicolumn{4}{|l|}{ Fuel price } \\
\hline Hard coal & $\$ 2011 / G J$ & $\begin{array}{l}\text { Europe in 2015: } 108.5 \$ / \mathrm{t} \\
\text { China in 2015:95 } \$ / \mathrm{t}\end{array}$ & {$[-20 \% ;+20 \%]$} \\
\hline Natural gas & $\$_{2011} / G J$ & $\begin{array}{l}\text { Europe in 2015: } 11 \$ / M B t u \\
\text { China in 2015:10 \$/MBtu }\end{array}$ & {$[-20 \% ;+20 \%]$} \\
\hline Discount rate [real and post tax] & $\%$ & 8 & [-4 points $;+4$ points] \\
\hline \multicolumn{4}{|l|}{ Plant efficiency } \\
\hline Centrales charbon (PCI) & $\%$ & $45 \%$ & $49 \%$ \\
\hline Centrales charbon avec CCS & $\%$ & $36 \%$ & $40 \%$ \\
\hline Centrales gaz & $\%$ & $60 \%$ & $63 \%$ \\
\hline Centrales gaz avec CCS & $\%$ & $52 \%$ & $55 \%$ \\
\hline
\end{tabular}

Table 6: Parameters used to run sensitivity analyses

Results of sensitivity analyses reveal that only the discount rate, fuel prices and load factor variations have a real impact on the $L C O E$ merit order and $\mathrm{CO}_{2}$ switching prices ${ }^{40}$. For detailed results, see Tables 9 to 14 in Annex.

Coal LCoEs (with and without CCS) are more sensitive to standardized parameters variations than gas LCoEs (with and without CCS) except for fuel prices. It can mostly be explained by the fact that the share of the capital cost in the LCoE is higher for coal plants ( $45 \%$ for EU, $30 \%$ for China) than for gas plants (15\% for EU, $11 \%$ for China). Discount rate and load factor play a significant role in the capital cost calculation. Consequently, the more capitalistic power plants are, the higher their influence.

Note that in the EU, for reference coal plants, the capital cost share in the LCOE is higher than the fuel cost share (45\% vs $41 \%$ ) whereas in China the capital cost share is lower (30\% vs $62 \%$ ) than the fuel cost. For gas plants, the fuel cost share in the LCOE is much higher than the capital cost share: $80 \%$ vs $15 \%$ in European countries and $87 \%$ vs $11 \%$ in China. The fuel cost share in the LCoE is higher in China than in European countries, mostly because Chinese capital and labor costs are lower which mechanically increases the fuel cost share in the LCoE.

\footnotetext{
${ }^{39}$ Technical issues and higher efficiency penalties (and thus higher costs) induced by a lower load factor are not taken into account.

${ }^{40}$ Note that in our sensitivity analysis, the efficiency penalty induced by a CCS device is kept constant: 9 points for coal plants, 8 for gas plants. Thus, $\mathrm{LCOEs}$ and $\mathrm{CO}_{2}$ switching prices are less sensitive to plant efficiency variations than in the case where the efficiency penalty would also vary. The results of sensitivity analysis are not detailed here because they are less significant than the one obtained for discount rate, fuel prices and load factor (due to this constant efficiency penalty).
} 
Intra-technique switching prices are more sensitive for coal plants than for gas plants except for fuel prices. The explanation is the same as above: the share of the capital cost in the LCoE is higher for coal plants than for gas plants.

In European countries, when the $\mathrm{CO}_{2}$ price is null, the reference gas plant (and not coal plant) is the most profitable power plant type for 2 scenarios: mid-load and a $12 \%$ discount rate. In China, when the $\mathrm{CO}_{2}$ price is null, whatever the scenario, the reference coal plant is always the most profitable power plant type.

In European countries, I have shown that when the $\mathrm{CO}_{2}$ price is high enough, the CCS gas plant (rather than CCS coal plants) is the most profitable power plant type. Sensitivity analyses show there are only two scenarios for which CCS coal plant and not CCS gas plant is the most profitable power plant type: a coal price reduced by $20 \%$ and a $4 \%$ discount rate which corresponds to the public policy rate.

In China, it's the opposite: in the reference case, when the $\mathrm{CO}_{2}$ price is high enough, the CCS coal plant is more profitable than the CCS gas power plant type except for the mid-load scenario.

In European countries and in China, the $\mathrm{CO}_{2}$ price to switch from a reference plant to a CCS plant varies widely. However, a general trend appears. In Europe, the $\mathrm{CO}_{2}$ price to switch from a reference to a CCS plant is around $110 € / \mathrm{tCO}_{2}$ except for the discount rate and the mid-load scenarios.

In China, when techno-economic conditions do not allow gas plants to be the most profitable power plant type whatever the $\mathrm{CO}_{2}$ price, the $\mathrm{CO}_{2}$ price to switch from a reference to a CCS plant ranges from is around $30 €$. When gas plants are the most profitable power plant type for a given range of $\mathrm{CO}_{2}$ prices, the $\mathrm{CO}_{2}$ price to switch from a reference to a CCS plant is higher and ranges from 45 to $67 €$.

\section{What about 2030 ?}

According to many studies, CCS techniques could be mature in 2030. It means that, thanks to R\&D investments, economies of scale and learning by doing effects, CCS investment and operating costs should have decreased significantly in 2030. Mechanically, the $\mathrm{CO}_{2}$ price beyond which CCS plants become the most profitable power plant type should have decreased too. As a consequence, CCS power plant attractivity should be higher in 2030. Thus the question is: how much cheaper advanced $\mathrm{CO}_{2}$ capture systems will be compared to current technology.

As previously said, the costs of mature CCS plants provided by the public studies used in this paper are for 2015-2020, except the IEA and the DECC ${ }^{41}$ that respectively provide costs for 2015-2030 and 2013-2020-2028. However, given the delays/cancelation observed for CCS LSIPs, CCS has not yet taken off in the world. Thus the costs provided for 2015-2020 rather correspond to 2030 cost data.

To assess more precisely CCS costs in 2030, I refer to the DECC's study which is very recent (2013) and thus updated in comparison with the other studies (2009 to 2011), and moreover distinguishes costs for 2013, 2020 and $2030^{42}$.

The ZEP analysis doesn't particularly look at the cost reduction process, ie doesn't give cost projections for carbon transport and storage costs in 2030. As the DECC (2012) low cost path is "broadly in line with the ZEP estimates for early commercial costs", carbon transport and storage costs for 2030 are from the $\operatorname{DECC}(2012,2013)^{43}$. They correspond to offshore infrastructures.

\footnotetext{
${ }^{41}$ Alstom also gives CCS costs in 2015 and 2030 but its 2030 data are too much aggregated to be exploited.

${ }^{42}$ To project CCS costs in 2030 , the DECC refers to Rubin'studies $(2007,2010)$ which are considered as references. They use historical experience curves as the basis for estimating future cost trends for CCS power plants. They first assess the rates of cost reductions achieved by other energy and environmental process technologies in the past. Then by analogy with leading capture plant designs, they estimate future cost reductions that might be achieved by power plants with $\mathrm{CO}_{2}$ capture.

${ }^{43}$ A $25 \%$ cost reduction factor for Chinese costs is still applied.
} 
WU N. et al.'s paper (2013) considers CCS costs by 2030 by reducing capital and O\&M costs but do not modify fuel prices assumptions. This scenario of constant fuel prices has the advantage to isolate the learning by doing and economies of scale effects (Scenario 1). However, this assumption of constant fuel prices is rather unrealistic.

That's why, I have also made a fuel price scenario based on the WEO 2012 projections by 2030 ("New Policies scenario", 2012c) (Scenario 2). For steam coal prices by 2030, according to the IEA, the OECD coal price is "a proxy for international coal prices"; thus I adopt this value for the EU and China. For natural gas prices, I directly use the IEA projection for the EU, since there is none for China. There is currently an uncertainty on Chinese fuel prices effectively paid by utilities because prices are administered and often kept lower to avoid triggering high inflation rates. Moreover, there is a high fuel price heterogeneity between regions. Thus, for the future, the uncertainty is very high and, to our knowledge, there are no public projections on the future level of Chinese fuel prices. I assume that, by 2030, Chinese gas prices follow either Japanese prices (in 2011, 54\% of Chinese imports were liquefied natural gas whose price is supposed to follow the Japanese price (IEA, 2012b)) or European prices (relatively to the high volumes of natural gas which are imported, China has a bargaining power).

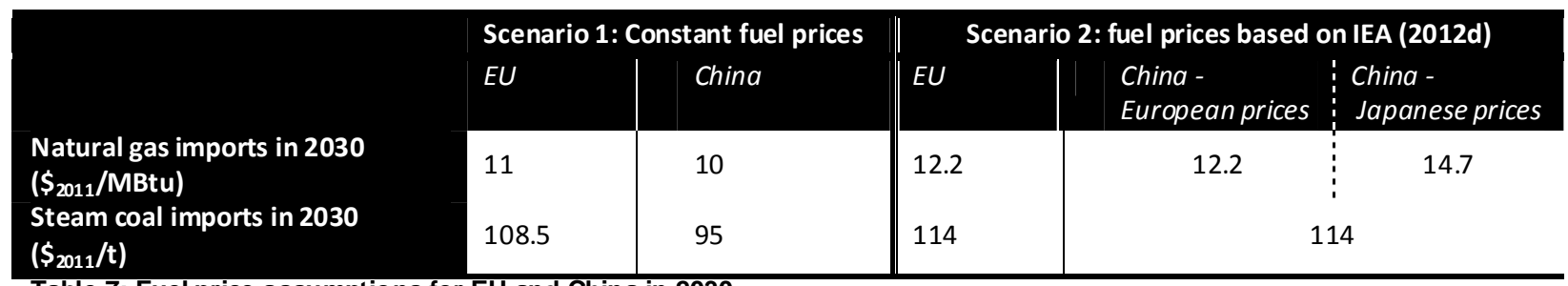

Table 7: Fuel price assumptions for EU and China in 2030

For detailed results see Tables 15 and 16 in Annex.

In the EU, if fuel prices are constant over the time, the CCS gas plant is the most profitable power plant type when the $\mathrm{CO}_{2}$ price is high enough (above $83 € / \mathrm{tCO}_{2}$ ). The same result is obtained if fuel prices follow the IEA trends (CCS gas plant is the most profitable power plant type above $86 € / \mathrm{tCO}_{2}$ ). However, the profitability frontier that divides CCS gas plants from CCS coal plants is thin.

It also should be noticed that the $\mathrm{CO}_{2}$ price that causes the switch from a coal plant to a gas plant is lower in the first scenario than in the second (which is more realistic) and both are higher than the 2015 value.

As a consequence, by 2030, European actors should invest in gas plants rather than coal plants, since the IEA forecasts $\mathrm{C} \mathrm{CO}_{2}$ price above $30 € / \mathrm{t}$ (2012c) (Figure 4). Contrary to China in 2030, European CCS power plants are still not profitable because of the low $\mathrm{CO}_{2}$ prices that are forecast.

As Figure 4 suggests, according to IEA's projections, coal plants burning international coal have still a future in Europe. CCS plants (coal or gas) are far away from being competitive (very high $\mathrm{CO}_{2}$ price compared to IEA forecasts: red points).

For China, the $\mathrm{CO}_{2}$ price beyond which CCS power plants become the most profitable power plant type is around $33 €(47 € / t$ on average by 2015). It's very low in comparison with the EU: more than $83 € / t$. As onshore $T / S$ costs are at least twice lower than offshore costs, in 2030, Chinese CCS coal plant with onshore transport and storage infrastructures could be the most profitable plant type for a $\mathrm{CO}_{2}$ price higher than $28 € / t$. This $\mathrm{CO}_{2}$ price level could be reached realistically in China: the IEA (2012a) forecasts a $\mathrm{CO}_{2}$ price at $20 € / \mathrm{t}$ in 2030 and $25 € / \mathrm{t}$ in 2035. Thus Chinese actors should keep in mind this 
when they invest in new power plants in the early 2020s (and choose CCS coal plants) ${ }^{44}$ or be ready to retrofit CCS by 2030 (Figure 5).

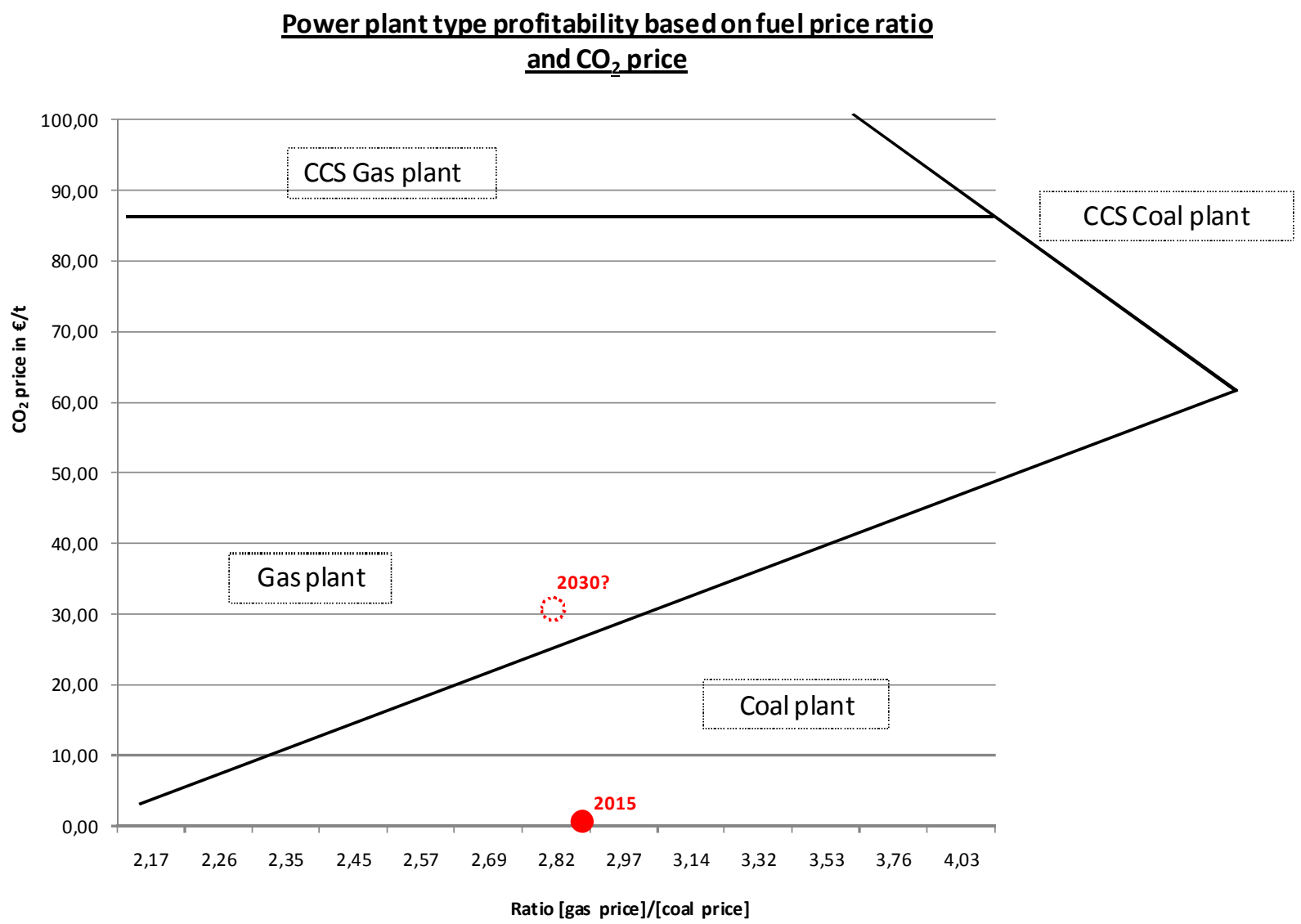

Figure 4: Profitability areas for power plant types based on fuel price ratio ${ }^{45}$ and $\mathrm{CO}_{2}$ price in the European Union. Simulations on the DECC study, offshore T/S costs.

\footnotetext{
${ }^{44}$ At least in the early 2020s because coal power plants have a lifetime of 40 years: with a rising $\mathrm{CO}_{2}$ price, reference coal plants would not be profitable for the lifetime project, contrary to CCS coal plants (not profitable in the early 2020s, but highly profitable in the early 2060 s, at the end of the lifetime).

${ }^{45}$ I have a similar approach to BLYTH W. and YANG M. (2006). Coal price is fixed and gas price varies.
} 


\section{Power plant type profitability based on fuel price ratio} and $\mathrm{CO}_{2}$ price

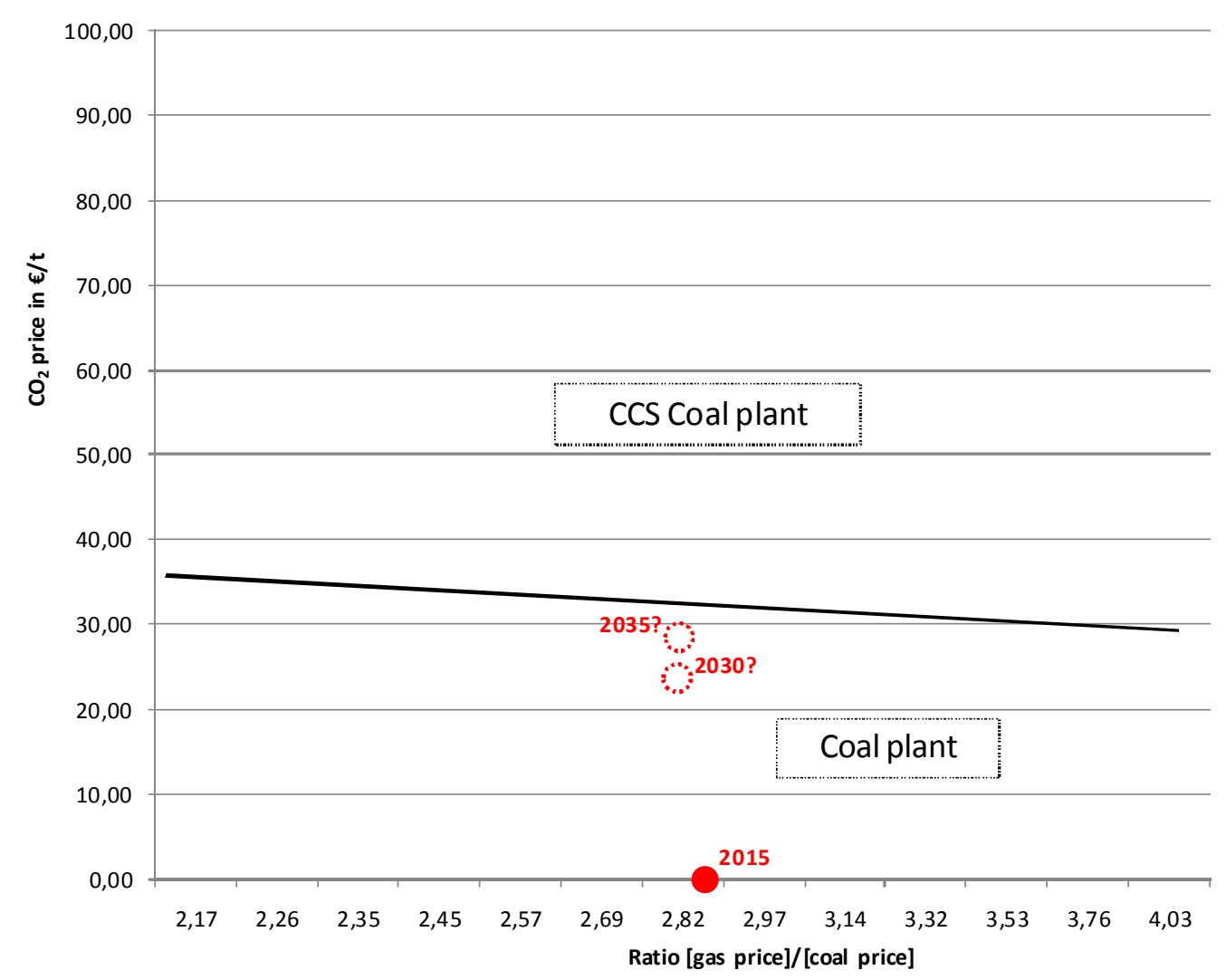

Figure 5: Profitability areas for power plant types based on fuel price ratio ${ }^{46}$ and $\mathrm{CO}_{2}$ price in China. Simulations on the DECC study, offshore T/S costs.

\section{Conclusion}

In this study, I have developed a methodology to objectively compare CCS costs provided by public studies. I have also shown that when CCS costs for a specific region, here China, are not given, a cost location factor approach can be adopted. Then, I have demonstrated that there exists several $\mathrm{CO}_{2}$ switching price; to be sure that a CCS power plant is the most profitable investment, both intra and intertechnique $\mathrm{CO}_{2}$ switching price have to be considered. This distinction have pointed out that in the $\mathrm{EU}$, contrary to common beliefs, CCS coal plants are not profitable when the $\mathrm{CO}_{2}$ price is higher than $60 € / \mathrm{t}$. Indeed, at $60 € / \mathrm{tCO}_{2}, \mathrm{CCS}$ coal plants become more profitable than reference coal plants but they are not the most profitable power plant type (gas plant is). For the record, $\mathrm{LCoEs}$ and these $\mathrm{CO}_{2}$ switching prices are calculated for baseload plants; indeed, costs soars when the load factor is lower. Last but not least, LCoEs and $\mathrm{CO}_{2}$ switching prices are highly sensitive to fuel prices (in absolute and relative terms) and were calculated, in this paper, with international prices (IEA (2012c) assumptions).

\footnotetext{
${ }^{46}$ I have a similar approach to BLYTH W. and YANG M. (2006). Gas price is fixed and coal price varies.
} 
This frame being established, this study shows that, given current power plant costs, with and without $\mathrm{CCS}, \mathrm{a} \mathrm{CO}_{2}$ price of $115 € / \mathrm{t}$ is required for CCS (gas) power plants to become the most profitable power plant type in the $\mathrm{EU}$ (offshore $\mathrm{T} / \mathrm{S}$ costs). Note that the European profitability frontier between CCS gas plants and CCS coal plants is thin. In China, CCS (coal) power plant becomes the most profitable type for a $\mathrm{CO}_{2}$ price higher than $33 € / \mathrm{t}$ with onshore transport and storage infrastructures and $47 € / \mathrm{t}$ with offshore infrastructures.

In 2030, with offshore carbon transport and storage costs, CCS plants are the most profitable power plant type for a $\mathrm{CO}_{2}$ price higher than 83-86 € in Europe (CCS gas plants) vs 31-33 $€ / t$ in China (CCS coal plants). As onshore T/S costs are at least twice lower than offshore costs, in 2030, Chinese CCS coal plant with onshore transport and storage infrastructures could be the most profitable plant type for a $\mathrm{CO}_{2}$ price higher than $28 € / t$. The WEO 2012 (New policy scenario) forecasts a $\mathrm{CO}_{2}$ price at $40 \$ / \mathrm{t}$ in the EU and $30 \$ / t$ in China by 2030. Thus, it can be said that in the EU, investors should choose gas plants without CCS and that in China, investors should choose CCS coal plants in the early 2020s by considering the lifetime of a coal plant or at least be ready for CCS retrofit in the early 2030s. Note that Chinese electricity prices are regulated; it could cause difficulties to CCS deployment. However structural reform could happen quickly. Last year, because of the coal price increase, many utilities lost money and there were several electricity shortages.

To make it more valuable for investment decisions and policy making, this study could be extended with the assessment of investment risk under uncertainty (relatively to the $\mathrm{CO}_{2}$ price, $\mathrm{CCS}$ techniques maturity...).

\section{Bibliography}

- Alstom, (2011), Cost Assessment of fossil power plants equipped with CCS under typical scenarios.

- BERNSTEIN L., LEE A., CROOKSHANK S., (2006), "Carbon dioxide capture and storage: a status report", Climate Policy, Vol.6, Issue 2, pp. 241-246.

- $\quad$ BEST D., LEVINA E., (2012), "Facing China's Coal Future", IEA Working Paper Series.

- BLYTH W., YANG M., (2006), "Impact of Climate Change Policy Uncertainty in Power Investment", International Energy Agency Working Paper Series.

- ConsensusEconomics, (2013), Asia Pacific Consensus Forecasts.

- DAHOWSKI R.T., LI X., DAVIDSON C.L., WEI N., DOOLEY J.J., GENTILE R.H., "Early Assessment of Carbon Dioxide Capture and Storage potential in China", $8^{\text {th }}$ annual Conference on Carbon Capture and Sequestration, 5 May 2009, Pittsburgh, Pennsylvannia.

- Department of Energy and Climate Change, Mott MacDonald, (2012), Potential cost reductions in CCS in the power sector.

- Department Of Energy and Climate Change, (2013), CCS Cost Reduction Taskforce.

- EPRI, (2009), Updated Cost and Performance Estimates for Clean Coal Techniques including $\mathrm{CO}_{2}$ Capture.

- European Commission, (2011), Roadmap for moving toward a competitive low-carbon economy in 2050.

- GIOVANNI E., RICHARDS K.R., (2010), "Determinants of the costs of carbon capture and sequestration for expanding electricity generation capacity", Energy Policy, Vol. 38, pp. 6026-6035.

- Global CCS Institute, (2011), The Global status of CCS: 2011.

- Global CCS Institute, (2013), The Global status of CCS: 2013 update.

- GRIMSTON M.C., KARAKOUSSIS V., FOUQEUT R., VAN DER VOST R., PEARSON P., LEACH M., (2001), "The European and global potential of carbon dioxide sequestration in tackling climate change", Climate Policy, Vol. 1, Issue 2, pp.155-171. 
- IEA ETSAP, (2010), Technology Brief E14.

- $\quad$ IEA, (2012a), Energy Technology Perspectives 2012.

- IEA, FINKENRATH M., (2011), Cost and Performance of Carbon Dioxide Capture from Power Generation.

- IEA, (2012b), Gas Pricing and Regulation, China's challenges and IEA experience.

- IEA, (2010), Projected Costs of Generating Electricity.

- IEA, (2013), Technology Roadmap, Carbon capture and storage.

- IEA, (2012c), World Energy Outlook 2012.

- $\quad$ IPCC, (2005), Carbon Dioxide Capture and Storage.

- IPCC, (2007), Contribution of Working Group III to the Fourth Assessment Report of the Intergovernmental Panel on Climate Change.

- JOUVET P.-A., SOLIER B., (2013), "An overview of $\mathrm{CO}_{2}$ cost pass-through to electricity prices in Europe", Energy Policy, Vol.61, pp.1370-1376.

- MIT, (2007), The Future of Coal.

- NETL, (2010a), Cost and Performance Baseline for Fossil Energy Plants - Volume 1: Bituminous Coal and Natural Gas to Electricity.

- NETL, (2010b), DOE/NETL Carbon dioxide capture and storage RD\&D roadmap.

- NZEC, (2009), China-UK Near Zero Emissions Coal Initiative - Carbon dioxide Capture from Coal-fired Power Plants in China, Summary Report for NZEC Work Package 3.

- PARK CHAN S., (2003), Study Guide, Fundamentals of engineering economics, Ed. Pearson.

- RUBIN E.S., CHEN C., RAO A.B., (2007), "Cost and Performance of Fossil Power Plants with $\mathrm{CO}_{2}$ capture and Storage", Energy Policy, Vol. 35 (9), pp. $4444-4454$.

- RUBIN E.S., MARKS A., MANTRIPRAGADA H., VERSTEEG P., KITCHIN J., (2010), Prospects for improved carbon capture technology - Report to the Congressional Research Service, from Carnegie Mellon University.

- $\quad$ RUBIN E. S., YEH S., ANTES M. et al., (2007), "Use of experience curves to estimate the future cost of power plants with $\mathrm{CO}_{2}$ capture", International Journal of Greenhouse Gas Control, vol. 1, nº 2, p. 188197.

- SIJM J., NEUHOFF K., CHEN Y., (2006), " $\mathrm{CO}_{2}$ cost pass-through and windfall profits in the power sector", Climate Policy, Vol. 6, p.49-72.

- The Oxford Institute for Energy Studies, HENDERSON J., (2011), The Pricing Debate over Russian Gas Exports to China.

- WorleyParsons, (2011), Economic assessment of carbon capture and storage techniques: 2011 update.

- WorleyParsons, Schlumberger, Baker \& McKenzie and EPRI, (2009), Strategic analysis of the global status of CCS.

- WU N., PARSONS J.E., POLENSKE K.R. (MIT), (2013), "The impact of future carbon prices on CCS investment for power generation in China", Energy Policy, Vol. 54, pp. 160-172.

- YANG M., BLYTH W., (2006), "Modeling Investment Risks and Uncertainties with Real Options Approach", International Energy Agency Working Paper Series.

- ZEP, (2011a), The Costs of $\mathrm{CO}_{2}$ Capture, Post - demonstration CCS in the EU.

- ZEP, (2011b), The Costs of $\mathrm{CO}_{2}$ Storage, Post - demonstration CCS in the EU.

- ZEP, (2011c), The Costs of $\mathrm{CO}_{2}$ Transport, Post-demonstration CCS in the EU.

- http://epp.eurostat.ec.europa.eu/portal/page/portal/eurostat/home/

- http://stats.oecd.org/

- http://www.bloomberg.com/news/print/2013-05-27/china-coal-falls-to-lowest-in-almost-four-yearson-manufacturing.html 
- http://www.developpement-durable.gouv.fr/IMG/pdf/26-_captage_et_le_stockage_du_CO2.pdf

\begin{tabular}{l|c|c|c|c|}
\multicolumn{1}{l|}{$\begin{array}{l}\text { Annex } \\
\text { EU }\end{array}$} & $\begin{array}{l}\text { Gas/Coal Prices } \\
\text { Ratio }\end{array}$ & Coal plant LCoEs & Gaz plant LCoEs & Coal minus Gas LCoEs \\
\hline Reference case & 2.7 & $60 € / \mathrm{MWh}$ & $68 € / \mathrm{MWh}$ & $8 € / \mathrm{MWh}$ \\
\hline Coal price reduced by 20\% & 3.3 & $54 € / \mathrm{MWh}$ & $68 € / \mathrm{MWh}$ & $14 € / \mathrm{MWh}$ \\
\hline Coal price increased by 20\% & 2.2 & $65 € / \mathrm{MWh}$ & $68 € / \mathrm{MWh}$ & $3 € / \mathrm{MWh}$ \\
Gas price reduced by 20\% & 2.1 & $60 € / \mathrm{MWh}$ & $57 € / \mathrm{MWh}$ & $3 € / \mathrm{MWh}$ \\
Gas price increased by 20\% & 3.2 & $60 € / \mathrm{MWh}$ & $79 € / \mathrm{MWh}$ & $19 € / \mathrm{M}^{2} W h$ \\
\hline
\end{tabular}

Table 8: Relative competitiveness of coal and gas plants depending on different scenarios of fuel prices in Europe, IEA 2011

\begin{tabular}{|c|c|c|c|c|c|c|}
\hline European LCoE & BAU [ref case] & $\begin{array}{l}\text { Discount rate: } \\
4 \%\end{array}$ & $\begin{array}{l}\text { Discount rate: } \\
12 \%\end{array}$ & $\begin{array}{l}\text { Coal price: }+/- \\
20 \%\end{array}$ & $\begin{array}{l}\text { Gas price: }+/- \\
20 \%\end{array}$ & Mid-load \\
\hline Coal plant & $60 € / M W h$ & $-24 \%$ & $25 \%$ & $+/-9 \%$ & - & $31 \%$ \\
\hline CCS coal plant & $106 € / M W h$ & $-27 \%$ & $29 \%$ & $+/-7 \%$ & - & $32 \%$ \\
\hline Gas plant & $68 € / M W h$ & $-6 \%$ & $7 \%$ & - & $+/-18 \%$ & $13 \%$ \\
\hline CCS gas plant & $104 € / M W h$ & $-7 \%$ & $8 \%$ & - & $+/-13 \%$ & $24 \%$ \\
\hline
\end{tabular}

Table 9: Sensitivity analysis results on European LCoEs

\begin{tabular}{|c|c|c|c|c|c|c|}
\hline Chinese LCoE & BAU [ref case] & $\begin{array}{l}\text { Discount rate: } \\
4 \%\end{array}$ & $\begin{array}{l}\text { Discount rate: } \\
12 \%\end{array}$ & $\begin{array}{l}\text { Coal price: }+/- \\
20 \%\end{array}$ & $\begin{array}{l}\text { Gas price: }+/- \\
20 \%\end{array}$ & Mid-load \\
\hline Coal plant & $40 € / \mathrm{MWh}$ & $-17 \%$ & $16 \%$ & $+/-12 \%$ & - & $39 \%$ \\
\hline CCS coal plant & $63 € / M W h$ & $-21 \%$ & $19 \%$ & $+/-10 \%$ & - & $44 \%$ \\
\hline Gas plant & $58 € / M W h$ & $-4 \%$ & $5 \%$ & - & $+/-18 \%$ & $12 \%$ \\
\hline CCS gas plant & $75 € / M W h$ & $-6 \%$ & $6 \%$ & - & $+/-16 \%$ & $18 \%$ \\
\hline
\end{tabular}

Table 10: Sensitivity analysis results on Chinese LCoEs, onshore carbon transport and storage

\begin{tabular}{|c|c|c|c|c|c|c|}
\hline Chinese LCoE & BAU [ref case] & $\begin{array}{l}\text { Discount rate: } \\
4 \%\end{array}$ & $\begin{array}{l}\text { Discount rate: } \\
12 \%\end{array}$ & $\begin{array}{l}\text { Coal price: }+/- \\
20 \%\end{array}$ & $\begin{array}{l}\text { Gas price: }+/- \\
20 \%\end{array}$ & Mid-load \\
\hline Coal plant & $40 € / \mathrm{MWh}$ & $-17 \%$ & $16 \%$ & $+/-12 \%$ & - & $39 \%$ \\
\hline CCS coal plant & $69,5 € / M W h$ & $-19 \%$ & $18 \%$ & $+/-10 \%$ & - & $40 \%$ \\
\hline Gas plant & $58 € / \mathrm{MWh}$ & $-4 \%$ & $5 \%$ & - & $+/-18 \%$ & $12 \%$ \\
\hline CCS gas plant & $83 € / M W h$ & $4 \%$ & $6 \%$ & - & $+/-16 \%$ & $16 \%$ \\
\hline
\end{tabular}

Table 11: Sensitivity analysis results on Chinese LCoEs, offshore carbon transport and storage

\begin{tabular}{|c|c|c|c|c|c|c|c|c|c|}
\hline EU - 2015 & & $\begin{array}{l}\text { BAU [ref } \\
\text { case] }\end{array}$ & $\begin{array}{l}\text { Discount } \\
\text { rate: } 4 \%\end{array}$ & $\begin{array}{l}\text { Discount } \\
\text { rate: } 12 \%\end{array}$ & $\begin{array}{l}\text { Coal price: } \\
-20 \%\end{array}$ & $\begin{array}{l}\text { Coal price: } \\
+20 \%\end{array}$ & $\begin{array}{l}\text { Gas price: } \\
-20 \%\end{array}$ & $\begin{array}{l}\text { Gas price: } \\
+20 \%\end{array}$ & Mid-load \\
\hline $\begin{array}{l}\text { Intra- } \\
\text { technique }\end{array}$ & $\begin{array}{l}\text { Coal to } \\
\text { CCS coal }\end{array}$ & 67 & $-23 \%$ & $34 \%$ & $-3 \%$ & $3 \%$ & - & - & $47 \%$ \\
\hline $\begin{array}{l}\mathrm{CO}_{2} \\
\text { switching } \\
\text { price }\end{array}$ & $\begin{array}{l}\text { Gas to CCS } \\
\text { gas }\end{array}$ & 115 & $-9 \%$ & $39 \%$ & - & - & $-5 \%$ & $5 \%$ & $30 \%$ \\
\hline Inter- & Coal to gas & 20 & $94 \%$ & $x$ & $66 \%$ & $-66 \%$ & $x$ & $132 \%$ & $x$ \\
\hline $\begin{array}{l}\text { technique } \\
\mathrm{CO}_{2} \\
\text { switching } \\
\text { price }\end{array}$ & $\begin{array}{l}\text { Coal to } \\
\text { CCS gas } \\
\text { Gas to CCS } \\
\text { coal }\end{array}$ & $\begin{array}{r}60 \\
146\end{array}$ & $\begin{array}{l}11 \% \\
-50 \%\end{array}$ & $\begin{array}{l}-16 \% \\
-41 \%\end{array}$ & $\begin{array}{l}13 \% \\
-18 \%\end{array}$ & $\begin{array}{l}-13 \% \\
18 \%\end{array}$ & $\begin{array}{l}-29 \% \\
30 \%\end{array}$ & $\begin{array}{l}29 \% \\
-30 \%\end{array}$ & $\begin{array}{l}-15 \% \\
104 \%\end{array}$ \\
\hline
\end{tabular}

Table 12: Sensitivity analysis results on European $\mathrm{CO}_{2}$ switching prices 


\begin{tabular}{|c|c|c|c|c|c|c|c|c|c|}
\hline \multicolumn{2}{|c|}{ China - 2015 onshore } & $\begin{array}{l}\text { BAU [ref } \\
\text { case] }\end{array}$ & $\begin{array}{l}\text { Discount } \\
\text { rate: } 4 \%\end{array}$ & $\begin{array}{l}\text { Discount } \\
\text { rate: } 12 \%\end{array}$ & $\begin{array}{l}\text { Coal price: } \\
-20 \%\end{array}$ & $\begin{array}{l}\text { Coal price: } \\
+20 \%\end{array}$ & $\begin{array}{l}\text { Gas price: } \\
-20 \%\end{array}$ & $\begin{array}{l}\text { Gas price: } \\
+20 \%\end{array}$ & Mid-load \\
\hline $\begin{array}{l}\text { Intra- } \\
\text { technique }\end{array}$ & $\begin{array}{l}\text { Coal to } \\
\text { CCS coal }\end{array}$ & 33 & $-23 \%$ & $34 \%$ & $-5 \%$ & $5 \%$ & - & - & $-34 \%$ \\
\hline $\begin{array}{l}\mathrm{CO}_{2} \\
\text { switching } \\
\text { price }\end{array}$ & $\begin{array}{l}\text { Gas to CCS } \\
\text { gas }\end{array}$ & 55 & $-11 \%$ & $12 \%$ & - & - & $-9 \%$ & $9 \%$ & $38 \%$ \\
\hline Inter- & Coal to gas & 44 & $18 \%$ & $-24 \%$ & $26 \%$ & $-26 \%$ & $-55 \%$ & $55 \%$ & $-40 \%$ \\
\hline $\begin{array}{l}\text { technique } \\
\mathrm{CO}_{2}\end{array}$ & $\begin{array}{l}\text { Coal to } \\
\text { CCS gas }\end{array}$ & 49 & $4 \%$ & $-7 \%$ & $14 \%$ & $-14 \%$ & $-33 \%$ & $33 \%$ & $-3 \%$ \\
\hline $\begin{array}{l}\text { switching } \\
\text { price }\end{array}$ & $\begin{array}{l}\text { Gas to CCS } \\
\text { coal }\end{array}$ & 16 & $-209 \%$ & $296 \%$ & $-148 \%$ & $148 \%$ & $247 \%$ & $-247 \%$ & $464 \%$ \\
\hline
\end{tabular}

Table 13: Sensitivity analysis results on Chinese $\mathrm{CO}_{2}$ switching prices -onshore T/S costs

\begin{tabular}{|c|c|c|c|c|c|c|c|c|c|}
\hline \multicolumn{2}{|c|}{ China - 2015 offshore } & $\begin{array}{l}\text { BAU [ref } \\
\text { case] }\end{array}$ & $\begin{array}{l}\text { Discount } \\
\text { rate: } 4 \%\end{array}$ & $\begin{array}{l}\text { Discount } \\
\text { rate: } 12 \%\end{array}$ & \begin{tabular}{|l} 
Coal price: \\
$-20 \%$
\end{tabular} & $\begin{array}{l}\text { Coal price: } \\
+20 \%\end{array}$ & $\begin{array}{l}\text { Gas price: } \\
-20 \%\end{array}$ & $\begin{array}{l}\text { Gas price: } \\
+20 \%\end{array}$ & Mid-load \\
\hline \multirow{2}{*}{$\begin{array}{l}\text { Intra- } \\
\text { technique } \\
\mathrm{CO}_{2} \\
\text { switching } \\
\text { price }\end{array}$} & $\begin{array}{l}\text { Coal to } \\
\text { CCS coal }\end{array}$ & 42 & $-18 \%$ & $26 \%$ & $-4 \%$ & $4 \%$ & - & - & $-28 \%$ \\
\hline & $\begin{array}{l}\text { Gas to CCS } \\
\text { gas }\end{array}$ & 81 & $-7 \%$ & $8 \%$ & - & - & $-6 \%$ & $6 \%$ & $26 \%$ \\
\hline \multirow{3}{*}{$\begin{array}{l}\text { Inter- } \\
\text { technique } \\
\mathrm{CO}_{2} \\
\text { switching } \\
\text { price }\end{array}$} & Coal to gas & 44 & $18 \%$ & $-24 \%$ & $26 \%$ & $-26 \%$ & $-55 \%$ & $55 \%$ & $-40 \%$ \\
\hline & $\begin{array}{l}\text { Coal to } \\
\text { CCS gas }\end{array}$ & 60 & $3 \%$ & $-6 \%$ & $11 \%$ & $-11 \%$ & $-27 \%$ & $27 \%$ & $-2 \%$ \\
\hline & $\begin{array}{l}\text { Gas to CCS } \\
\text { coal }\end{array}$ & 39 & $-84 \%$ & $119 \%$ & $-60 \%$ & $60 \%$ & $100 \%$ & $-100 \%$ & $187 \%$ \\
\hline
\end{tabular}

\begin{tabular}{|c|c|c|c|c|}
\hline EU & & 2015 & 2030 - Scenario 1 & 2030 - Scenario 2 \\
\hline \multirow{2}{*}{$\begin{array}{l}\text { Intra-technique } \mathrm{CO}_{2} \\
\text { switching price }\end{array}$} & Coal to CCS coal & 77 & 65 & 66 \\
\hline & Gas to CCS gas & 133 & 83 & 86 \\
\hline \multirow{3}{*}{$\begin{array}{l}\text { Inter-technique } \mathrm{CO}_{2} \\
\text { switching price }\end{array}$} & Coal to gas & 9 & 13 & 25 \\
\hline & Coal to CCS gas & 60 & 43 & 51 \\
\hline & Gas to CCS coal & 194 & 149 & 131 \\
\hline
\end{tabular}

Table 15: European Union $\mathrm{CO}_{2}$ switching prices by 2030 -offshore T/S costs

\begin{tabular}{|c|c|c|c|c|c|}
\hline China & & 2015 & 2030 - Scenario 1 & $\begin{array}{l}2030 \text { - Scenario } 2 \\
\text { European prices }\end{array}$ & $\begin{array}{l}2030 \text { - Scenario } 2 \\
\text { Japanese prices }\end{array}$ \\
\hline \multirow{2}{*}{$\begin{array}{l}\text { Intra-technique } \\
\mathrm{CO}_{2} \text { switching price }\end{array}$} & Coal to CCS coal & 45 & 31 & 33 & 33 \\
\hline & Gas to CCS gas & 93 & 57 & 63 & 69 \\
\hline \multirow{3}{*}{$\begin{array}{l}\text { Inter-technique } \\
\mathrm{CO}_{2} \text { switching price }\end{array}$} & Coal to gas & 37 & 51 & 69 & 105 \\
\hline & Coal to CCS gas & 61 & 54 & 66 & 89 \\
\hline & Gas to CCS coal & 60 & $\mathrm{x}$ & $x$ & $\mathrm{x}$ \\
\hline
\end{tabular}

Table 16: Chinese $\mathrm{CO}_{2}$ switching prices by 2030 - offshore T/S costs 



\section{Working Paper Series}

$n^{\circ}$ 2014-02

$n^{\circ}$ 2014-02

$n^{\circ}$ 2014-01
Carbon prices and CCS investment: comparative study between the European Union and China

By Marie Renner

Dynamic Impacts on Growth and Intergenerational Effects of Energy Transition in a Time of Fiscal Consolidation

By Frédéric Gonand

$n^{\circ} 2013-12$

Readiness and Avoided deforestation policies: on the use of the REDD fund By Philippe Delacote and Gabriela Simonet

Reducing deforestation and forest degradation: leakage or synergy?

By Arild Angelsen and Philippe Delacote

Greenhouse gas mitigation in Chinese agriculture: distinguishing technical and economic potentials

By Wen Wang, Frank Koslowski, Dominic Moran, Dali Rani Nayak, Eli

Saetnan, Erda Lin, Liping Guo, Guodong Han and Xiaotang Jug

Carbon and energy prices under uncertainty: A theoretical analysis of fuel switching with non-equally efficient power plants

By Vincent Bertrand

$n^{\circ} 2013-08$

A stochastic generalized Nash-Cournot model for the northwestern European natural gas markets: The S-GaMMES model

By Ibrahim Abada and Pierre-André Jouvet

$n^{\circ} 2013-07$
Governance of $\mathrm{CO}_{2}$ markets: Lessons from the EU ETS

By Christian de Perthuis and Raphael Trotignon

Contact us :

Chaire Economie du Climat - Palais Brongniart (4e étage)

28 Place de la Bourse, 75002 Paris

Tel : +33 (0)173019331

Email : contact@chaireeconomieduclimat.org

Climate Economics

Chair

Paris-Dauphine University CDC Climat 